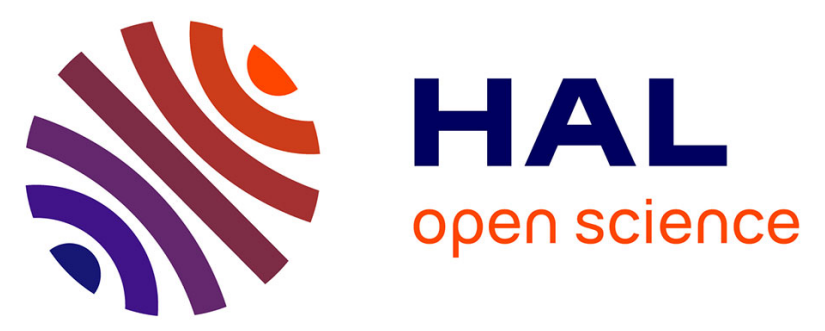

\title{
Mantle convection in the Middle East: Reconciling Afar upwelling, Arabia indentation and Aegean trench rollback
}

Claudio Faccenna, Thorsten W. Becker, Laurent Jolivet, Mehmet Keskin

\section{- To cite this version:}

Claudio Faccenna, Thorsten W. Becker, Laurent Jolivet, Mehmet Keskin. Mantle convection in the Middle East: Reconciling Afar upwelling, Arabia indentation and Aegean trench rollback. Earth and Planetary Science Letters, 2013, 375, pp.254-269. 10.1016/j.epsl.2013.05.043 . insu-00859093

\section{HAL Id: insu-00859093 https://hal-insu.archives-ouvertes.fr/insu-00859093}

Submitted on 28 Nov 2014

HAL is a multi-disciplinary open access archive for the deposit and dissemination of scientific research documents, whether they are published or not. The documents may come from teaching and research institutions in France or abroad, or from public or private research centers.
L'archive ouverte pluridisciplinaire HAL, est destinée au dépôt et à la diffusion de documents scientifiques de niveau recherche, publiés ou non, émanant des établissements d'enseignement et de recherche français ou étrangers, des laboratoires publics ou privés. 


\title{
Mantle convection in the Middle East: Reconciling Afar upwelling, Arabia indentation and Aegean trench rollback
}

- Claudio Faccenna ${ }^{a}$

- Thorsten W. Becker ${ }^{\mathrm{b}}$

- Laurent Jolivet ${ }^{\mathrm{c}}$

- Mehmet Keskin ${ }^{\mathrm{d}}$

- $\quad{ }^{a}$ LET, Laboratory of Experimental Tectonics, Università Roma Tre, Rome, Italy

- ${ }^{\mathrm{b}}$ Department of Earth Sciences, University of Southern California, Los Angeles, CA 90089, USA

- $\quad{ }^{\mathrm{c}}$ Institut des Sciences de la Terre d'Orléans, Université Orleans, France

- ${ }^{\mathrm{d}}$ Department of Geological Engineering, Istanbul University, 34320 Avc1lar, Istanbul, Turkey

\begin{abstract}
The Middle East region represents a key site within the Tethyan domain where continental break-up, collision, backarc extension and escape tectonics are kinematically linked together. We perform global mantle circulation computations to test the role of slab pull and mantle upwellings as driving forces for the kinematics of the Arabia-Anatolia-Aegean (AAA) system, evaluating different boundary conditions and mantle density distributions as inferred from seismic tomography or slab models. Model results are compared with geodetically inferred crustal motions, residual topography, and shear wave splitting measurements. The AAA velocity field with respect to Eurasia shows an anti-clockwise toroidal pattern, with increasing velocities toward the Aegean trench. The best match to these crustal motions can be obtained by combining the effect of slab pull exerted in the Aegean with a mantle upwelling underneath Afar and, more generally, with the large-scale flow associated with a whole mantle, Tethyan convection cell. Neogene volcanism for AAA is widespread, not only in the extensional or subduction settings, but also within plates, such as in Syria-Jordan-Israel and in Turkey, with geochemical fingerprints similar of those of the Afar lava. In addition, morphological features show large uplifting domains far from plate boundaries. We speculate that the tectonic evolution of AAA is related to the progressive northward entrainment of upwelling mantle material, which is itself associated with the establishment of the downwelling part of a convection cell through the segmented Tethyan slab below the northern Zagros and Bitlis collision zone. The recently established westward flow dragged Anatolia and pushed the Aegean slab south-westward, thus accelerating backarc extension. Our model reconciles Afar plume volcanism, the collision in the Bitlis mountains and northern Zagros, and the rapid increase of Aegean trench rollback in a single coherent frame of large scale mantle convection, initiated during the last $\sim 40 \mathrm{Ma}$
\end{abstract}

Keywords : mantle convection; Middle East; continental deformation; volcanism

\section{Introduction}

The Arabia-Anatolia-Aegean (AAA) system represents a key regional setting within the Tethyan domain where continental break-up, collision, backarc extension, and escape tectonics are intricately linked. This interacting plate system with a wealth of available 
geological and geophysical constraints offers a chance to evaluate the dynamics behind the motions and deformation of the plates.

The geodetically imaged crustal motions are spectacular; they show marked, counterclockwise rotation of the velocity field with respect to Eurasia (Fig. 1a; Kreemer and ChamotRooke, 2004, Reilinger et al., 2006 and Le Pichon and Kreemer, 2010). Arabia behaves as a rigid plate moving NE to NNE, producing spreading in the Red Sea and Gulf of Aden and collision against Eurasia along the Bitlis-Zagros. While convergence in Iran is accommodated by distributed northward decrease in the relative velocity, toward the west, the Anatolian plate moves at present coherently at an average rate of $\sim 2 \mathrm{~cm} / \mathrm{yr}$, separated from Eurasia by the North Anatolian Fault (Reilinger et al., 2006). In the west, the Aegean plate is moving SW at $\sim 3.3 \mathrm{~cm} / \mathrm{yr}$ following the retreat of the Aegean trench (Kreemer and Chamot-Rooke, 2004 and Reilinger et al., 2006). Overall, the collisional AAA zone shows a circular velocity pattern, accelerating toward the Aegean trench, with a rotation pole for Anatolia-Eurasia positioned north of the Nile delta (Fig. 1a, see also Le Pichon and Kreemer (2010)).

a

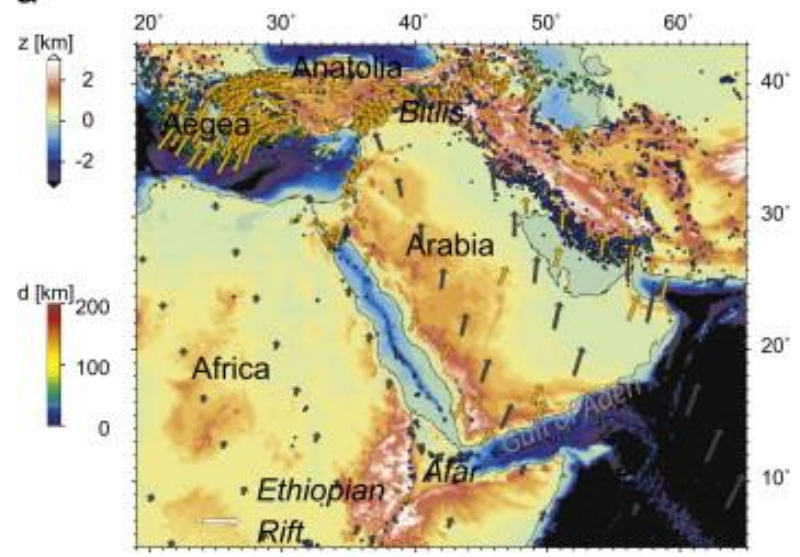

C

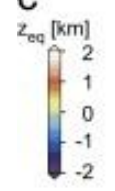

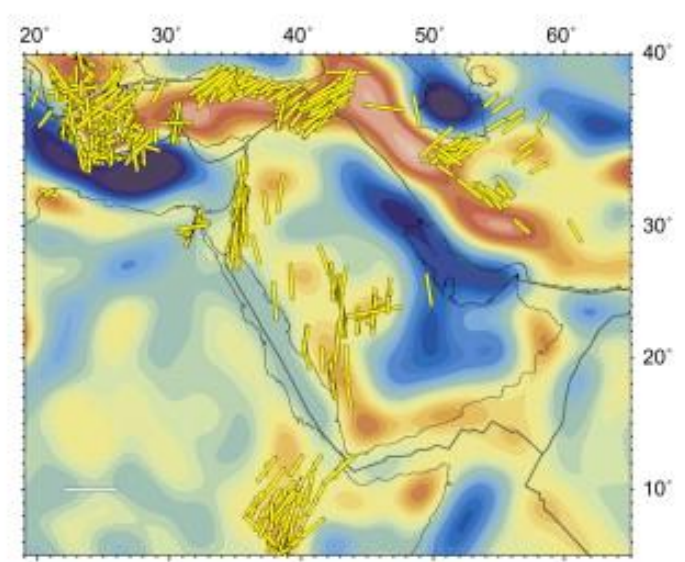

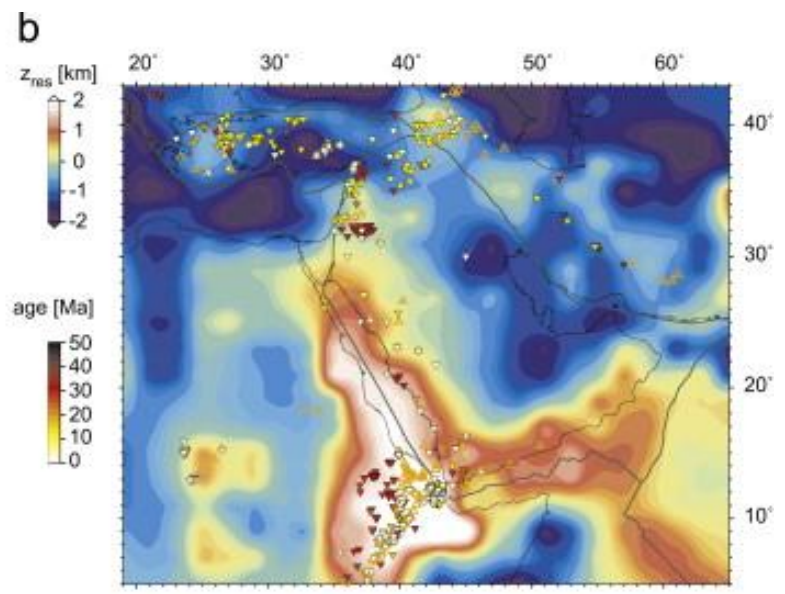

d

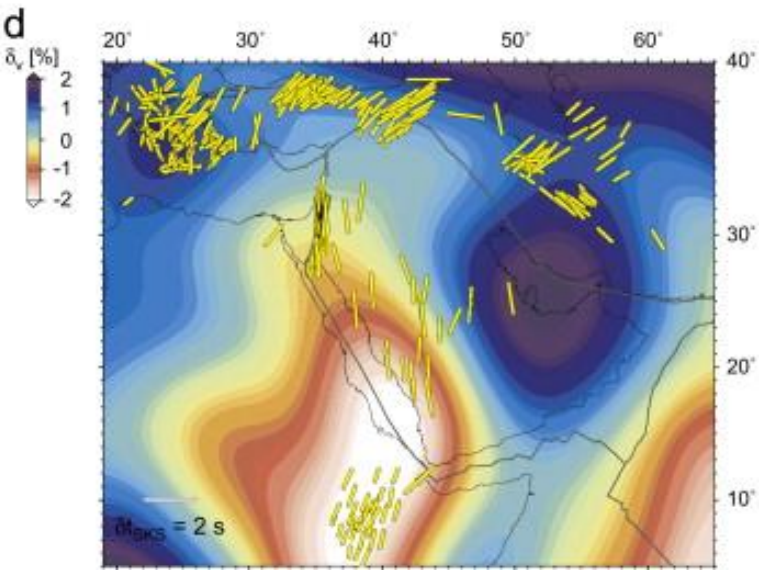

Fig. 1. Topography and deformation indicators for the Arabia-Anatolia-Aegean system. (a) Geodetic velocity field (ArRajehi et al., 2010) in a Eurasia fixed reference frame (orange vectors) compared to geological plate motions from NUVEL-1A (DeMets et al., 1994; dark gray vectors), topography from ETOPO1, and seismicity (Engdahl et al., 1998), color coded by depth, $z$, with major geographic features labeled. (b) Residual topography, $z_{\text {res }}$, estimated by correcting smoothed actual topography for crustal isostatic adjustment using the CRUST2.0 model (Bassin et al., 2000) using the same method as in Becker and Faccenna (2011). Open triangles are Holocene volcanoes from Siebert and Simkin (2002), and colored inverted triangles show all volcanic rocks younger than $50 \mathrm{Ma}$ in the EarthChem database compilation available at www.earthchem.org as of 05/2012. Plate boundaries (dark green) are 
modified from NUVEL-1A (DeMets et al., 1994) to include an Anatolian plate, as in Becker and Faccenna (2011). (c) Dynamic topography estimated by converting free-air gravity anomalies using a $50 \mathrm{mGal} / \mathrm{km}$ conversion, assuming a mantle density of $3300 \mathrm{~kg} / \mathrm{m}^{3}$ (Craig et al., 2011). (d) SMEAN composite tomography model (Becker and Boschi, 2002) averaged over uppermost mantle depths from 150 to $400 \mathrm{~km}$ (see also Figs. 2 and S1). Both (c) and (d) are superimposed with SKS splitting observations (from the compilation of Wüstefeld et al. (2009), updated 05/2012) where yellow sticks show the "fast azimuths," i.e. fast velocity polarization orientation from azimuthal anisotropy, (c) for all available splits, and (d) for station-averaged estimates. (For interpretation of the references to color in this figure legend, the reader is referred to the web version of this article.)

The dynamics of the AAA system are not only reflected in horizontal motions, but also seen in the remarkable geomorphic features indicating rapid and recent vertical motions. High plateaux are diffuse within the system from the Ethiopia-Arabian dome to the TurkishIranian plateau, both standing at $\sim 2 \mathrm{~km}$ elevation (Şengör et al., 2003). In contrast, subsiding regions are found behind the Aegean trench and in the Makran-Persian Gulf (Barrier and Vrielynck, 2010). The vertical motion of these areas is Neogene to Recent and its origins are still poorly understood (Şengör et al., 2003 and Gögüus and Pysklywec, 2008). Residual topography, computed by removing the crustal isostatic topography component from the actual present-day topography, shows positive features over the Ethiopia-Kenya swells extending northward along the Red Sea and Anatolia-Iran, while a negative signal is seen along the Hellenic trench-Persian Gulf (Fig. 1b and c). This indicates that at least part of the topography could be related to mantle dynamics (Daradich et al., 2003, Husson, 2006 and Moucha and Forte, 2011; Faccenna and Becker, 2010; Forte et al., 2010; Becker and Faccenna, 2011 and Komut et al., 2012).

Volcanism is diffuse over the region and mainly focused on the large Ethiopian-Yemen igneous province (Fig. 1b). Intraplate volcanism is also present in Syria-Jordan and Israel, far from the plate boundary, with large basaltic effusions and within the collisional zone, i.e. Eastern Anatolia, where the volcanic signature gets complicated by the mixed contributions of different geochemical sources (Keskin, 2003). Fig. 1b shows a general agreement between volcanism and positive residual topography, suggesting a link between mantle dynamics, volcanism, and surface dynamics.

Fig. 1c and d shows shear-wave splitting estimates of azimuthal seismic anisotropy of the upper mantle (mainly SKS, from the compilation of Wüstefeld et al. (2009), 05/2012 update), on top of dynamic topography, now as estimated directly from free air gravity using the conversion and filtering approach of Craig et al. (2011). The fast polarization axes of SKS splitting correlate poorly with the mantle shear that may be inferred from plate motions, both in Anatolia and in Arabia (e.g. Hansen et al., 2006 and Hansen et al., 2012), illustrating the complexity of the system. The large-scale mantle structure as imaged by seismic tomography shows low velocity anomalies rooted beneath the Afar system as well as in northern ArabiaSyria-Jordan, and high velocity anomalies beneath the Aegean and the Zagros-Makran trenches (Fig. 1d, also see Hansen et al., 2012). This pattern suggests that the deeper mantle component of the AAA system is dominated by strong seismic velocity anomalies that are indicative of large temperature differences, and hence vigorous convection.

Several prior studies analyzed the kinematics and the dynamics of the region, addressing such problems as to why Anatolia is moving westward, what is driving Arabia toward the north with respect to Africa, or why the Hellenic trench retreats so fast, and different models have been proposed. The presence of an active subduction system and the westward acceleration of the geodetic field argue in favor of the action of the pull of the Aegean slab system as the 
main engine, sucking Anatolia-Aegea toward the trench (Le Pichon, 1982, Faccenna et al., 2006 and Le Pichon and Kreemer, 2010). The motion of Arabia is more problematic. It has been related to slab-pull (Bellahsen et al., 2003 and Reilinger and McClusky, 2011), even if there is evidence that the slab is broken beneath the Bitlis suture zone limiting active subduction to the Makran trench (Keskin, 2003, Keskin, 2007, Şengör et al., 2003, Şengör et al., 2008, Hafkenscheid et al., 2006 and Faccenna et al., 2006). Another possible explanation is that the Afar plume is pushing Arabia northward, even though the constant velocity attained by Arabia during the last $\sim 30 \mathrm{Ma}$ (Reilinger and McClusky, 2011) contrasts with the expected progressive decrease in velocity from a main upwelling plume phase at $\sim 32 \mathrm{Ma}$ (van Hinsbergen et al., 2011). More recently, it has been proposed that mantle drag related to a large-scale convection cell could efficiently pull continental plates toward collisional zones, thus favouring indentation (Alvarez, 2010 and Becker and Faccenna, 2011). This model also agrees with previous studies which suggested that Arabia is dynamically tilted by mantle convection toward the Persian Gulf (Daradich et al., 2003, Forte et al., 2010 and Moucha and Forte, 2011).

However, basic questions still remain. For example, it is unclear how the large-scale convection cell associated with the African deep mantle plume relates to the smaller-scale one associated with the pull of the Aegean slab, and what causes intraplate volcanism in the Middle East. Moreover, it is unclear if the high plateaux in the collisional belt are caused by active mantle upwellings, lithospheric delamination, or by crustal thickening during collision.

The aim of this paper is to test different hypotheses about the driving forces of the ArabiaAnatolia-Aegean system. Our results show the importance of mantle flow for driving the system, reconciling Afar plume volcanism, the collision within the Bitlis, and the rapid backward acceleration of the Aegean trench.

\section{Mantle dynamics inferred from tomography and anisotropy}

Several structural models have been proposed for the mantle underneath the Africa-Middle East-Aegean region. Most seismological models show a marked low velocity region over the Ethiopian-Yemen dome, extending north toward the Red Sea, up to Arabia and the Middle East (Figs. 2 and S1). Whether the Afar and Arabian low velocity zones are rooted in the lower mantle, and, more specifically, whether they are connected to the deep mantle, African low shear velocity anomaly, are debated questions. 3D shear wave tomography first showed the linkage between the deep mantle structure and the Ethiopian province (Ritsema et al., 1999, Mégnin and Romanowicz, 2000, Grand, 2002, Simmons et al., 2009, Simmons et al., 2010 and Ritsema et al., 2011). Similarly, global $P$-wave tomography models explored the connection between the Afar hot region and deep structures ( Montelli et al., 2006, Li et al., 2008 and Hansen et al., 2012). Regional models explored the presence and the position of the low velocity anomalies in some detail ( Benoit et al., 2006, Bastow et al., 2005 and Bastow et al., 2008) also showing a deep deflection of the low velocity anomaly toward the lower mantle one ( Park et al., 2007, Park et al., 2008 and Hansen et al., 2012). 


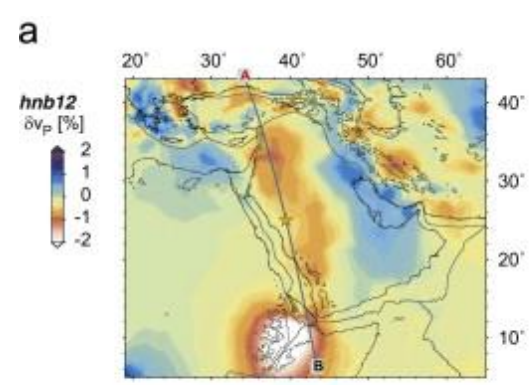

d

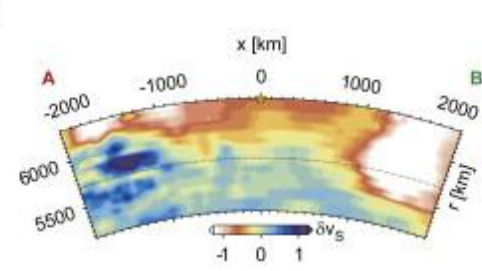

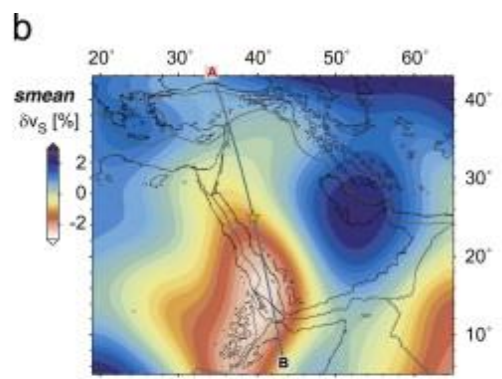

e

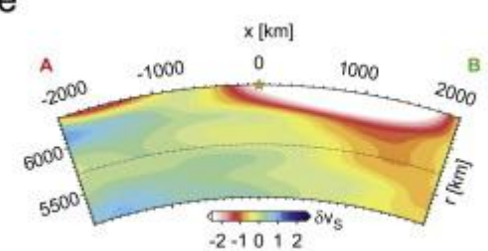

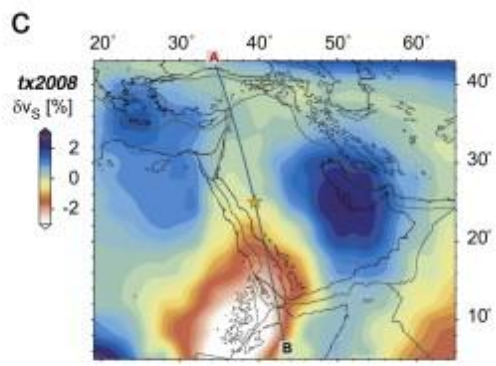

f

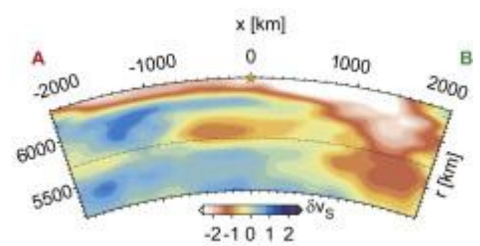

Fig. 2. Comparison of tomographically imaged structure underneath the study region (also see Fig. S1). Maps (a)-(c) show $250 \mathrm{~km}$ depth layer of models HNB12 (Hansen et al., 2012), SMEAN (Becker and Boschi, 2002), and TX2008 (Simmons et al., 2007), correspondingly. Smoothed elevation contours are overlaing in $2000 \mathrm{~m}$ contours for positive topography, plate boundaries (dark green) from Bird (2002). Dark cyan profiles are plotted in the underneath (d)-(f), correponding to the model shown in map above; dashed line indicates $660 \mathrm{~km}$. (For interpretation of the references to color in this figure legend, the reader is referred to the web version of this article.)

In northern Arabia, upper mantle, low velocity anomalies have been imaged by both $P$-wave and $S$-wave models ( Benoit et al., 2006, Park et al., 2007 and Park et al., 2008). Recently, regional $S$-velocity structure for Arabia and East Africa has been inferred by jointly inverting surface and body waves ( Chang et al., 2010 and Chang and Van der Lee, 2011), indicating that the low velocity zone beneath Afar is perhaps distinct from the low velocity zone beneath northern Arabia, implying a two-plume origin. Conversely, other recent models favor a shallow upper mantle connection of the Arabia low-velocity anomaly to the Afar plume, i.e. a single plume, perhaps dragged northward (Fig. 2; Hansen et al., 2012).

Regional and global studies also show low velocity anomalies in the uppermost parts of the upper mantle below Anatolia, above what can be inferred to be a deformed slab that is stagnating within the transition zone, partially detached from the lithosphere (Faccenna et al., 2006, Lei and Zhao, 2007, van Hinsbergen et al., 2010 and Biryol et al., 2011). The Hellenic subduction zone shows a $40-50^{\circ}$ north-dipping, high velocity anomaly marked by seismicity down to intermediate depth $(\sim 200 \mathrm{~km})$. Lower mantle, high velocity anomalies have also been detected beneath the Hellenic trench down to $\sim 1400 \mathrm{~km}$ (Piromallo and Morelli, 2003, Faccenna et al., 2003, Bijwaard et al., 1998, van Hinsbergen et al., 2005 and the SIMBAAD Team, 2012). High velocity anomalies are present also beneath the Zagros-Makran collision zone (Agard et al., 2011) but the resolution over this area is relatively low.

Fig. 2 shows a comparison between three global tomography models: $P$-wave model HNB12 (Hansen et al., 2012), which includes more regional data than Li et al. (2008) on which it is based, and $S$-wave tomography from the composite SMEAN (Becker and Boschi, 2002) and TX2008 (Simmons et al., 2009). It can be seen that (1) low-velocity anomalies are well defined beneath Afar, connect to the lower mantle, and extend north toward the Red Sea; (2) low-velocity anomalies are also found beneath the northern Arabia-Middle East region but there, they do not seem to connect to the lower mantle. The recent $P$-wave model (Hansen et 
al., 2012) shows a more pronounced slow anomaly compared to the other global models, widespread at shallow levels also beneath Anatolia, and Iran; and (3) high velocity anomalies are located beneath the Aegean and the Persian Gulf; they get more pronounced and enlarge downward at mid-mantle level, as part of the larger Tethyan anomaly.

Mantle anisotropy as reflected in shear wave splitting shows (Fig. 1d) roughly NE-SW trending apparent fast polarization axes north of the East African rift in Ethiopia (e.g. Gashawbeza et al., 2004) which rotate to mainly N-S "fast orientations" in Arabia and Israel (e.g. Hansen et al., 2006 and Kaviani et al., 2009), mainly NE-SW trending orientations in Anatolia and in central Iran (e.g. Biryol et al., 2010), turning to a more northerly trend in the Aegean, and a more NW-SE direction below the Zagros. Regional-scale patterns of relatively simple azimuthal anisotropy alternate with more complex signatures, such as a mix of null observations and large spatial gradients in fast orientations within Iran (e.g. Kaviani et al., 2009).

The interpretation of anisotropy in terms of mantle flow is not straightforward (see, e.g., Long and Becker (2010), for a recent review), and both lithospheric and a mantle origins of the observed patterns have been suggested for the region (e.g., Hansen et al., 2006 and Biryol et al., 2010). Below, we will explore the predictions for anisotropy from mantle flow modeling; those can provide a baseline to evaluate the feasibility of suggested asthenospheric flow scenarios such as northward transport of a plume.

\section{Quantitative mantle flow and anisotropy modeling}

To quantify the contribution of mantle heterogeneity such as due to plumes and slabs to mantle circulation and plate motions, we compute instantaneous mantle flow from seismic tomography by converting velocity anomalies to temperature (e.g., Hager and Clayton, 1989, Lithgow-Bertelloni and Silver, 1998 and Moucha and Forte, 2011). We solve the Stokes equation for incompressible flow in a global, spherical shell using a finite-element approach (Zhong et al., 2000). The basic approach is discussed in Becker and Faccenna (2011) and Miller and Becker (2012). We test several, geologically-motivated models of lateral viscosity variations as well as several density models to explore the effects of the different components of the AAA convection system. The goal is not so much to find the best model that matches all data at this point, but rather to identify some of the key regional convective processes as reflected in geological and geophysical observables.

The boundary conditions of the mantle flow computations are shear-stress free at the coremantle boundary and the surface, allowing for dynamically-consistent plate motions guided by weak zones prescribed at plate boundaries (Ricard and Vigny, 1989 and Zhong et al., 2000). Results are presented for a regional zoom-in of the global models around the ArabiaMiddle East, with all velocities rotated into a Eurasia-fixed reference frame whose corresponding best-fit Euler pole is obtained from the surface velocities within that plate.

The reference density structure for the mantle is based on SMEAN, with fast anomalies within inferred continental keels removed above $300 \mathrm{~km}$ to correct for shallow compositional effects. We use a Rayleigh number of $3.4 \times 10^{8}$ (defined as in Zhong et al. (2000)) with temperature scaled such density anomalies go with shear wave velocity anomalies as $d \ln \rho / d \ln V_{\mathrm{S}}=0.2$. This constant scaling is adopted for simplicity; it does not take depth-dependent mineral physics relationships into account (e.g., Forte, 2007), nor do we allow for compositional anomalies besides keels. However, such complications should mainly affect the amplitude but 
not the geometry of mantle flow (cf. Gurnis et al., 2000). In addition, we tested other density models such as the global $P$ wave models MIT08 by Li et al. (2008) and HNB12 by Hansen et al. (2012), the global $S$ wave models TX2008 (Simmons et al., 2007), LH08 (Lebedev and Van der Hilst, 2008), and the regional model by Chang and Van der Lee (2011).

Density models can also be inferred for slabs alone, based on seismicity in Wadati-Benioff zones and/or inferred past subduction (e.g. Hager, 1984, Ricard et al., 1993 and LithgowBertelloni and Richards, 1998), or by mixed models that explore the respective roles of slabs versus tomography and edge forces (e.g. Becker and O'Connell, 2001, Conrad and LithgowBertelloni, 2002, Ghosh et al., 2010 and Stadler et al., 2010). Here, we consider upper mantle models that are entirely or partially based on slabs inferred from the Engdahl et al. (1998) seismicity based, RUM slab geometry of Gudmundsson and Sambridge (1998), following Ghosh et al. (2010). No crustal density anomalies or other effects leading to lithospheric driving forces due to gravitational potential energy variations, besides those imaged by tomography, are considered.

We use a Newtonian viscous rheology with background viscosities for the lithosphere (depth $z \leq 100 \mathrm{~km})$, upper mantle $(100<z \leq 660 \mathrm{~km})$, and lower mantle $(z>660 \mathrm{~km})$ of $5 \times 10^{22}, 10^{21}$, and $5 \times 10^{22} \mathrm{~Pa}$ s, respectively. In weak zones, the viscosity is 0.01 times that of the remaining lithosphere. Weak zones are $300 \mathrm{~km}$ wide, cross-cut the whole lithosphere, and follow the major plate boundaries as shown in Fig. 1, with the exception of the Arabia-Eurasia margin (Fig. S2a). This simple model achieves a good general match to global plate velocities and the geoid ( Becker, 2006 and Miller and Becker, 2012), and we explore additional lateral viscosity variations or variations in weak zone geometry as described below.

The mantle flow model results for the region are then evaluated in the light of the present-day geodetic velocity fields by comparing horizontal surface motions. Additionally, we consider geomorphological information concerning the vertical motion and predictions of "dynamic topography." For the latter, the normal stresses generated at the surface by viscous flow are used to infer the instantaneous surface deflection that would be expected because of convection (Ricard et al., 1984 and Richards and Hager, 1984). Assuming that all non-crustal topography is due to active flow, this signal can be compared to observed topography once the effect of crustal isostatic adjustment is removed to arrive at "residual topography" as shown in Fig. 1b (e.g. Daradich et al., 2003 and Gurnis et al., 2000).

Another constraint for mantle flow is provided by seismic anisotropy which in the upper mantle most likely reflects the alignment of intrinsically-anisotropic, single crystals of olivine into lattice-preferred orientation (LPO) textures under mantle flow (e.g., Long and Becker, 2010). Our approach consists of assuming that flow is steady-state for the few Myr needed to achieve saturated textures, following tracer particles in the mantle circulation until stable LPOs, as predicted by the mineral physics theory of Kaminski et al. (2004), are reached at each desired location. Then, we assign pressure and temperature-dependent elastic tensors to the resulting 3D model of anisotropy from 50 to $410 \mathrm{~km}$ depth (Becker et al., 2006a). From this elastic anisotropy, we compute synthetic seismograms assuming lateral homogeneity on Fresnel zone lengths $(\sim 100 \mathrm{~km})$, such that the expected splitting can be computed for arbitrary back-azimuths (Becker et al., 2006b). However, here we will only consider stationaveraged splits and mainly discuss our models in terms of the average angular misfit, $\langle\Delta \alpha\rangle$, of apparent fast axes for all available non-null splitting measurements (334 for the study region; Fig. 1d). 


\section{Results}

We next illustrate the dynamics of the system using a few selected models to highlight the main driving processes. To isolate the role of suction produced by the subducting slab, we first show results from a global, upper mantle slab model where a density anomaly is regionally found along the Aegean trench only (Fig. 3a). The effect of the subducting Aegean slab produces mantle suction, i.e. dragging plates toward the subduction zone, driving the Aegean and Anatolia toward SW and WSW, respectively. The Aegean is moving rapidly, similar to what is observed, and Anatolia is moving at $\sim 1 \mathrm{~cm} / \mathrm{yr}$, accounting for $\sim$ half of its geodetic motion, with respect to Eurasia. The suction exerted by the slab produces an unrealistic westward motion of both Arabia and Africa in the Eurasia fixed reference frame, mainly because Eurasia is being dragged relatively eastward by western Pacific slabs. The regional correlation with actual plate velocities is poor. However, the mantle flow pattern produced by the slab produces a rather good fit with seismic anisotropy in Anatolia and eastern Aegean, but not in Arabia nor in the central Aegean. These results show that part of the asthenospheric flow beneath Aegea and Anatolia is likely related to the subduction of the Aegean slab. 

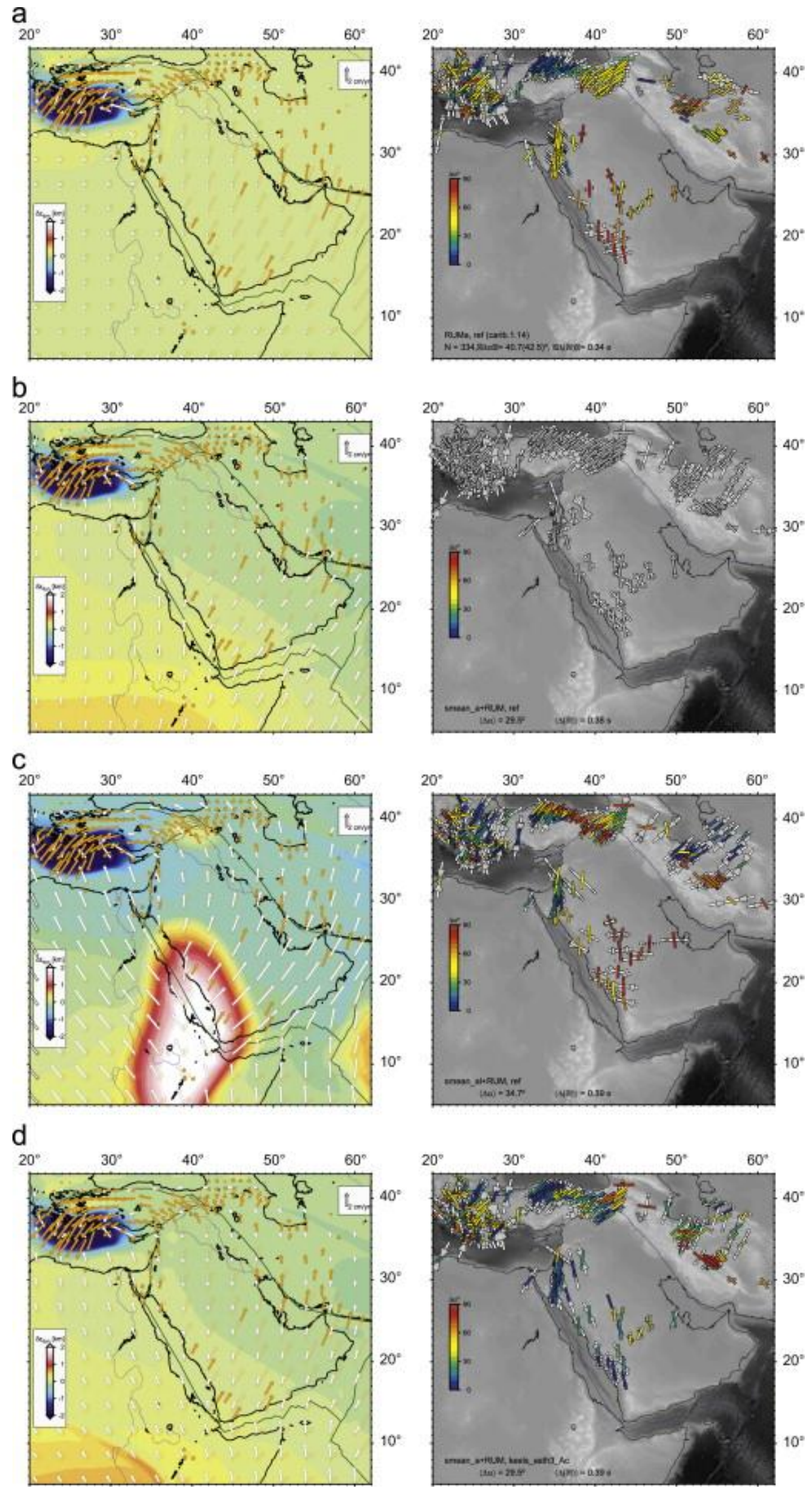

Fig. 3. Mantle flow solutions for four, illustrative example models for the AAA system. Left column: surface velocity field (white arrows) compared with geodetic velocity (orange arrows, averaged from 
the original vectors shown in Fig. 1a) with respect to Eurasia reference frame, with background indicating dynamic topography estimates. Right column: shear wave splitting measurements indicated by sticks, colored by angular misfit of "fast azimuths" with model predictions (gray) whose backazimuthal variations are denoted by wedges and two different stick lengths for fast axes and delay times, respectively (see Becker et al., 2006b and Miller and Becker, 2012, for details). Inset shows the regional arithmetic averages for the angular misfit, $\langle\Delta \alpha\rangle$, and the delay time misfit, $\langle\Delta(\delta t)\rangle$, for all 334 non-zero measurements of Fig. 1d. (a) Flow produced by upper mantle density anomaly assigned to the Wadati-Benioff zones only (slab driven flow); (b) flow produced by density anomaly within Wadati-Benioff zones and lower mantle convection produced by density anomaly scaled from the SMEAN model; (c) flow produced by density anomaly within the Wadati-Benioff zones, lower mantle anomalies, and convection produced by slow velocity anomaly only (from SMEAN) in the upper mantle. (d) As in (b) but with a low viscosity channel extending northward from Afar to Israel, sensuHansen et al. (2006) (see Fig. S2b). (For interpretation of the references to color in this figure legend, the reader is referred to the web version of this article.)

The influence of the large-scale convection patterns induced by lower mantle density anomalies as inferred from tomography when added to that of the Aegean upper mantle slab is shown in Fig. 3b. Compared to the previous model, the velocity of Arabia is faster, on average $\sim 1 \mathrm{~cm} / \mathrm{yr}$, matching about half of its actual speed, and moving in the right direction. Africa's motion is also faster, faster than it should be, but also with a more northerly direction. In addition, the velocity field in Fig. $3 \mathrm{~b}$ matches the gradual velocity decrease observed across the Zagros and northern Iranian plateau, then fading out north of Kopet Dagh and Alborz. This model also provides a fairly good overall match for the mantle anisotropy ( $\langle\Delta \alpha\rangle$ $\sim 30^{\circ}$ ), with the exception of the Zagros and south Arabia. The results from the model in Fig. 3 b illustrate how superimposing a large-scale convection cell, driven by the superswell beneath Africa and the downwelling over the Tethyan slab (Becker and Faccenna, 2011), to the small-scale convection related to the Aegean slab improves the solution both in terms of plate velocity direction and mantle flow, although Arabia and Anatolia velocities are still underestimated. Dynamic topography shows a large scale tilting of Arabia toward the NE, in agreement with previous predictions (Daradich et al., 2003; Forte et al., 2010) with maximum uplift centered in southern Ethiopia.

To evaluate the influence of the upper mantle related to the Afar-Red Sea-Anatolia system, slow ("hot") upper mantle anomalies are added to the previous model in Fig. 3c. This leads to an overall increase of plate velocities, as expected, produced by the vigorous upwelling centered on the Afar and flowing toward the Aegean subduction zone. In this model, Arabia and Anatolia both move in the right direction, while Arabia moves faster and Anatolia slightly slower than observed; overall correlation for regional velocities is quite good. As expected, the contribution of the upper mantle anomaly leads to a strong dynamic topography signature in the Afar and Carlsberg Ridge ( $\sim 2 \mathrm{~km}$ of topography) and some hundreds of meters positive elevation in eastern Anatolia and the Caucasus, as discussed by Boschi et al. (2010). The faster Arabia motion degrades the correlation of the mantle anisotropy $\left(\langle\Delta \alpha\rangle=35^{\circ}\right)$ slightly with respect to the model in Fig. 3b. This is particularly evident in southern Arabia, where an upwelling produces radial mantle flow, striking perpendicularly to the observed NS trending anisotropy.

The delay time amplitudes of splitting measurements are a measure of the strength of anisotropy, yet typically less stable than the "fast azimuth." In our modeling approach, delay times are mainly controlled by the degree of LPO saturation. Guided by the good fit to $S K S$ 
splitting delay times achieved in other regions ( Becker et al., 2006b and Miller and Becker, 2012), we here chose a logarithmic strain of 0.75. For the AAA system, this choice leads to an overprediction of delay times by $\sim 0.4 \mathrm{~s}$ (Fig. 3 ). We mainly take this as an indication for the heterogeneity and complexity of seismic anisotropy in the study region (Fig. 1c and d). This may indicate the role of lithospheric, frozen-in, anisotropy in obscuring the asthenospheric signal in some regions such as in Iran or the Hellenic.

The geometry of mantle convection for the model in Fig. 3c can be better shown on map view at different depths and cross sections (Fig. 4). At shallow upper mantle depths, the sinking of the Aegean slab and the upwelling of the mantle in Afar generate a large-scale current, upwelling in the Afar and downwelling in the Aegean, leading to some toroidal motion when interacting with the plate geometry. The convection cell is well represented by cross sections running from Afar to the Persian Gulf and to the Aegean trench (Fig. 4e and f). In addition, a shallow upwelling in eastern Anatolia generates a smaller-scale convection feature in the Aegean-central Anatolian plateau region. Much of these convection patterns are related to upper mantle motions, which efficiently drag plates and produce pronounced positive dynamic topography at the surface. At the base of the upper mantle, these perturbations flatten out, generating a more regular pattern of mantle flow trending toward WNW. 
a

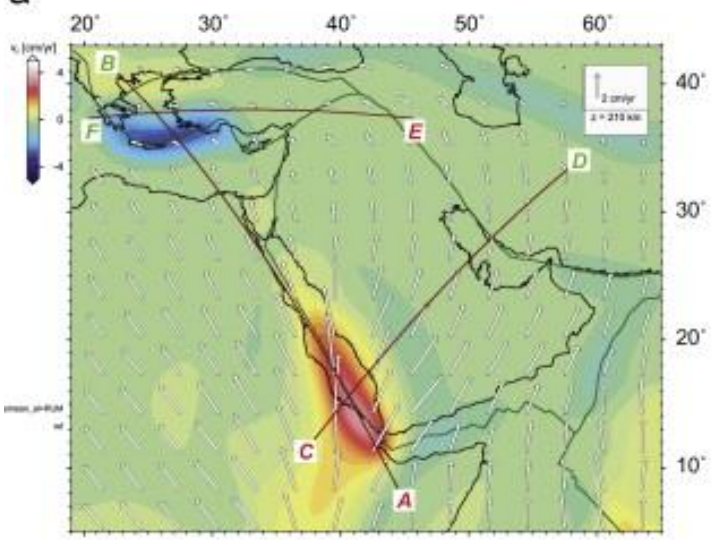

C

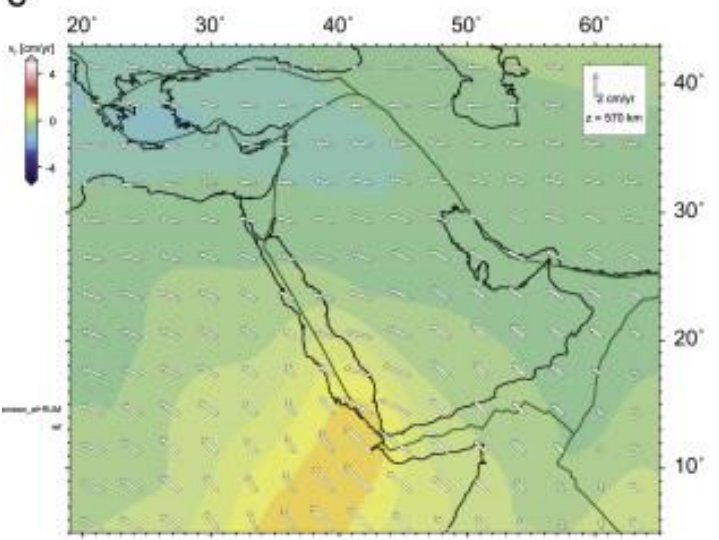

b

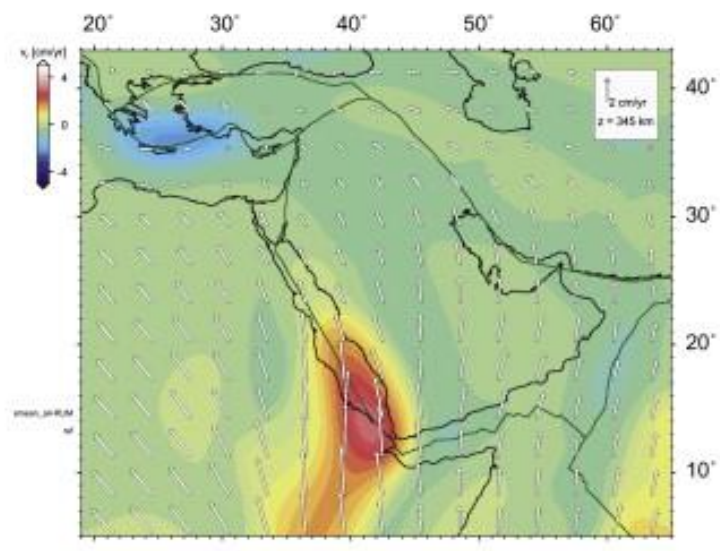

d

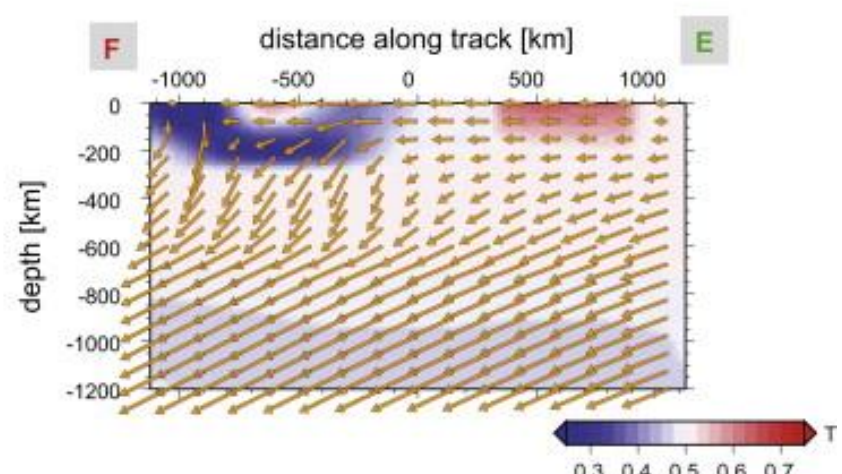

e distance along track $[\mathrm{km}]$

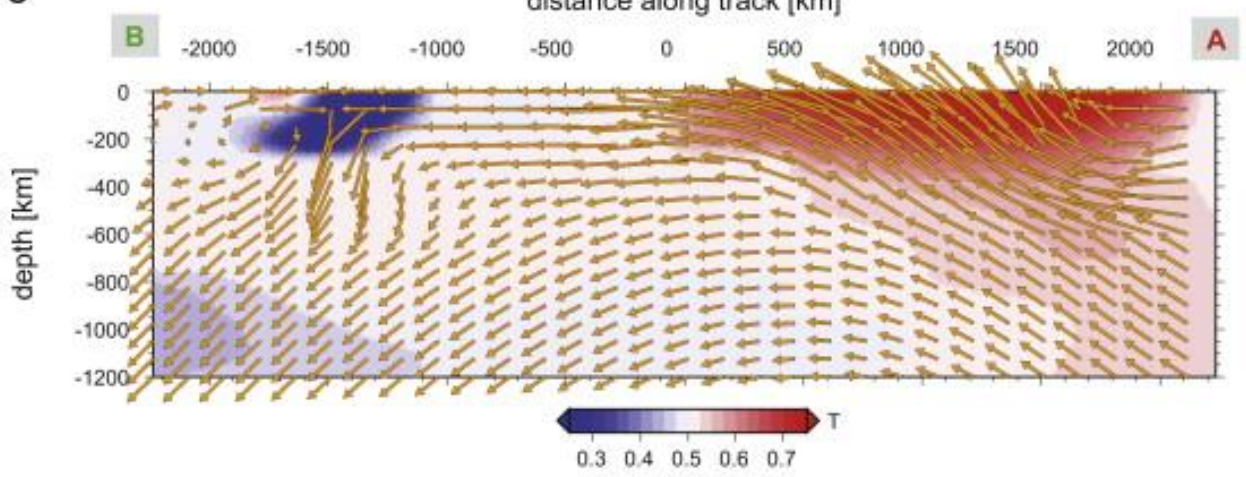

f

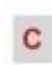
distance along track $[\mathrm{km}]$

D

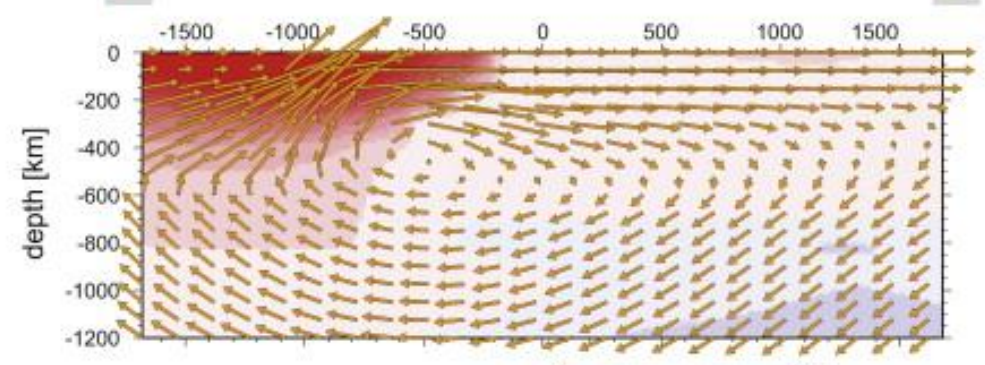

$\begin{array}{lllllll}0.3 & 0.4 & 0.5 & 0.6 & 0.7\end{array}$

Fig. 4. Mantle flow predictions at three different depths: (a) 210, (b) 345, and, (c), $570 \mathrm{~km}$ for the model in Fig. 3c, with vectors and background shading denoting horizontal and radial velocities, 
respectively, and velocities within three cross sections (d)-(f) as marked on (a), with background showing non-dimensional temperature.

The effect of lateral viscosity variations in modifying seismic anisotropy and flow is explored by adding complexities, including a low viscosity channel, to the density model in Fig. 3b (Fig. 3d). Compared to the reference viscosity (used in Fig. 3a-c), this model has a stiff $\left(500 \eta_{0}\right)$ keel underneath parts of the African plate, a low viscosity $\left(0.01 \eta_{0}\right)$ asthenosphere underneath oceanic plate regions, and a low viscosity channel $\left(0.01 \eta_{0}\right)$ from Afar to the Anatolia-Arabia margin, with a width of $\sim 500 \mathrm{~km}$ to the east of the Africa-Arabia plate boundary (Fig. S2b), where $\eta_{0}$ is the reference viscosity. This modification changes the anisotropy misfit $\langle\Delta \alpha\rangle$ to $29.5^{\circ}$, and particularly improves the match in Arabia (Fig. 3d). While the geometry of our channel is only meant to illustrate the general effects, this flow model provides a quantitative test of previous suggestions that the Afar upwelling is guided by a low viscosity mantle north beneath the Red Sea and western Arabia (Hansen et al., 2006) or toward the north beneath Arabia (Chang et al., 2011).

We computed mantle flow and seismic anisotropy for a large number of models, and a representative selection of results for different density models and different choices for lateral viscosity variations are shown in Fig. 5 . We show misfits as measured by linear correlation coefficient for global plate velocities (a), regional plate velocities (b), and for the average misfit of the "fast azimuth" from seismic anisotropy (c). Such a representation in misfit matrix form allows assessing the combined effects of the different parameters that were illustrated in Fig. 3 (cf. Miller and Becker, 2012). For example, the role of the low viscosity channel in Fig. $3 \mathrm{~d}$ can be compared to models with oceanic asthenosphere and keels alone. Moreover, the role of density models and the relevance of different model assumptions, such as on the geometry of weak zones, and regional plate coupling, can be assessed. At a regional scale, the best predictions of plate velocities when measured in terms of correlation are obtained by adopting the SMEAN composite model with upper mantle slabs added. Overall, the presence of a sub-oceanic plate asthenosphere improves the fit for velocity (e.g. Becker, 2006). This is also true for the presence of a low viscosity channel beneath Red Sea (cf. Hansen et al., 2006), and Fig. 5 provides an estimate of the sensitivity of details of the viscosity variations underneath Arabia on shear wave splitting estimates (Table 1). 

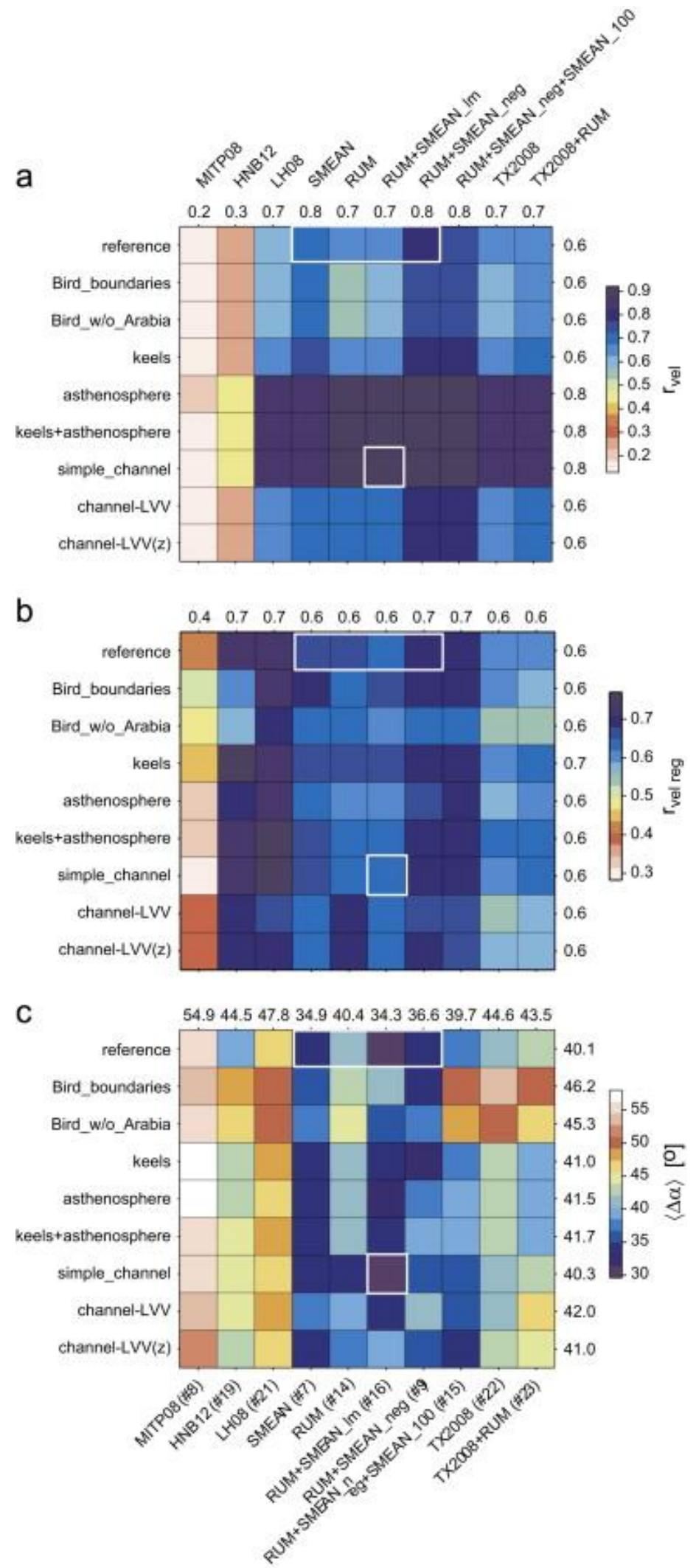

Fig. 5. Misfit matrices for a subset of all global flow models considered (cf. Miller and Becker, 2012), illustrating the effect of different choices of density (columns) and lateral viscosity variation (rows) models for, (a), global plate motion correlations, (b), regional plate motion correlations, and, (c), average angular misfits of shear wave splitting predictions. White boxes show the models illustrated in Fig. 3. For legend, see Table 1. 
Table 1. Legend for density and viscosity models considered in the misfit matrix plots in Fig. 5

Mantle density models

MITP08

HNB12

LH08

SMEAN

RUM

RUM+SMEAN_lm

RUM+SMEAN_neg
Li et al. (2008) (MIT gorup) global $P$ wave model, scaled to temperature in whole mantle.

Hansen et al. (2012) $P$ wave model in whole mantle, building on MITP08, highlighting effect of regional resolution improvement.

Lebedev and Van der Hilst (2008) $S V$ wave model in upper mantle, SMEAN (Becker and Boschi, 2002) in lower mantle.

Composite $S$ wave model with anomalies underneath continental keels down to $300 \mathrm{~km}$ removed.

Density anomalies in upper mantle only, as inferred from Wadati-Benioff zone geometry as assigned from the RUM model (Gudmundsson and Sambridge, 1998).

RUM plus density anomalies in the lower mantle inferred from SMEAN tomography.

Like RUM+SMEAN_lm, but additionally slow ("hot") velocity anomalies in the upper mantle from SMEAN, as in Ghosh et al. (2010).

Like RUM+SMEAN_neg, but additionally all velocity

RUM+SMEAN_neg+SMEAN_100 anomalies in the uppermost $100 \mathrm{~km}$ ("lithospheric anomalies") from SMEAN.

Global mantle temperature anomalies inferred from the

TX2008 TX2008 $S$ wave tomography model of Simmons et al. (2007).

TX2008+RUM

RUM upper mantle slabs as in RUM, lower mantle density anomalies from TX2008.

Models of lateral variations in viscosity as shown in different rows of the misfit matrices in Fig. 5

Reference

Bird_boundaries

Bird_wo_Arabia

Keels

Asthenosphere

Keels+asthenosphere

simple_channel
Only radial viscosity variations besides weak zone geometry prescribed in the lithosphere with modified NUVEL1 geometry as in Becker and Faccenna (2011), as in Fig. 4.

Same width and viscosity reduction for weak zones as in reference, but geometry taken from Bird (2003), as in Fig. 2.

Same as Bird_boundaries, but no weak zone between NW Arabia and Eurasia.

Same as reference, but stiff (factor 500 viscosity increase) continental keels down to $300 \mathrm{~km}$ depth as inferred from the 3SMAC model (Nataf and Ricard, 1996).

Sub-oceanic plate reduction of viscosity by a factor of 0.01 in the depths between 100 and $300 \mathrm{~km}$.

Combined effect of keels and asthenosphere.

Reference model with factor 0.01 viscosity reduction along a channel from Afar to Isreal between 100 and $300 \mathrm{~km}$ depth. 
Channel-LVV

Channel-LVV $(z)$
Reference model with lateral viscosity variations inferred from scaling the depth-averaged velocity anomalies in LH08 between 100 and $300 \mathrm{~km}$ depth to $\sim$ four orders of magnitude lateral variations of viscosity (cf. Fig. 1d), yielding a low viscosity channel similar to simple_channel.

As channel-LVV but allowing for depth-variations in lateral viscosity variations from 100 to $300 \mathrm{~km}$ depth.

Columns in Fig. 5 denote density models tested (details of model parameters are described in Becker and Faccenna, 2011 and Miller and Becker, 2012).

Overall, we find that the match to the shear wave splitting fast axes is very sensitive to details of the lateral viscosity variations, and in regions such as Iran we are close to the limit of what can usefully be explored with our global mantle flow models with homogeneous lithospheric rheology. Further model refinement may thus allow a better simultaneous fit to crustal velocities, dynamic topography, and seismic anisotropy. However, for our purposes, the results in terms of the major drivers of horizontal and vertical motions of the AAA plate system dynamics are robust.

In summary, the global circulation models show the importance of the combined effect of slab pull and plume push to match the velocity field of microplates in the Middle East. Model results indicate that slab pull is essential to drive Anatolia and the Aegean microplate toward the west and southwest, respectively. A large-scale upwelling in the Afar can be channeled into the upper mantle beneath the Red Sea, and such flow is necessary to match the motion of Arabia correctly. The AAA mantle flow patterns are dominated on different scales by convection systems that link the upwelling areas in Afar up to northern Arabia, to the shallow Aegean slab and, at larger depth, with the Tethyan slab.

\section{Geological evidence of mantle convection}

Geological evidence implies that the convection patterns reconstructed from our circulation models for the present-day were already activated in the Oligocene-late Eocene. The first trace of volcanism in Ethiopia dates back to $45 \mathrm{Ma}$ (Ebinger et al., 1993). It is probably at that time that a large volume of mantle emplaced at the base of the lithosphere (Ebinger and Sleep, 1998) while Africa was still a coherent plate, slowly moving NE toward Eurasia, consuming the Tethyan ocean and continental blocks along the Aegean-Bitlis trench system (Dercourt et al., 1986 and Barrier and Vrielynck, 2010). The deep mantle structure associated with the evolution of the Aegean subduction has previously been reconstructed from the seismically imaged high velocity anomalies, restored accounting for time-dependent convergence kinematics (Faccenna et al., 2003, van Hinsbergen et al., 2005 and van der Meer et al., 2010). The match between the absolute motion of the trench and the deep position of the high velocity anomalies into the lower mantle gives a maximum age for the entrance of the Aegean slab into the lower mantle of $\sim 50 \pm 10 \mathrm{Ma}$, probably after a stagnation phase of $\sim 10-20$ Myr duration on the $660 \mathrm{~km}$ discontinuity (Faccenna et al., 2013). This tectonic episode is extending regionally toward the Himalayan trench (Replumaz et al., 2004). The episode of slab avalanching at $\sim 45-50 \mathrm{Ma}$ in the Hellenic domain has been interpreted as the cause of stretching of the Sirte basin in north Africa (Capitanio et al., 2009). We infer that the 
large-scale, Tethyan convective cell that is active today (Becker and Faccenna, 2011) between Afar and the Tethyan subduction zone was operating at least from $~ 45 \mathrm{Ma}$.

The most apparent expression of the deep mantle upwelling is the outpouring of the Ethiopian large igneous province at $\sim 30 \mathrm{Ma}$ (e.g. Hofmann et al., 1997; Fig. 6a). The Red Sea and the Gulf of Suez (Fig. 1) rifted at the beginning of the Oligocene (Ghebreab, 1998). In the Red Sea, dykes and basaltic floods were emplaced during the Oligocene (Ghebreab, 1998 and Bosworth et al., 2005) and syn-rift deposits accumulated from the OligoceneMiocene ( 30-25 Ma) to Miocene (14 Ma) (Bayer et al., 1998, Garfunkel and Beyth, 2006 and ArRajehi et al., 2010). Thermochronology shows that uplift of the Red Sea rift shoulders commenced at $\sim 27 \mathrm{Ma}$ and peaked at $20 \mathrm{Ma}$ (Bosworth et al., 2005) and the erosion of the Blue Nile gorges commenced at 25-29 Ma (Pik et al., 2003). Inland uplift south and east of the Levant region began in the Late Eocene or early Oligocene. Stratigraphic and morphological studies (Garfunkel and Horowitz, 1966, Zilberman, 1991 and Avni et al., 2012 and references therein) show the presence of a regional truncation surface developed during the Oligocene from the northern Red Sea to southern Levant related to the formation of an $\sim 3000 \mathrm{~km} \times 1500 \mathrm{~km}$ crustal dome above the Afar plume (Şengör, 2001), with a widespread fluvial erosion that truncated the northern edge of this dome (Avni et al., 2012). Morphostratigraphic studies along Israel's mountainous backbone further indicate that inland uplift was episodic and occurred in three distinct phases: Late Eocene to Early Oligocene, late Early Miocene, and Middle to Late Pliocene (Gvirtzman et al., 2011). Inland uplift was associated with transport of huge amounts of clastics into the eastern Mediterranean. In the deep Levant basin the rate of sedimentation accelerated in an order of magnitude since the Late Eocene or Early Oligocene (Steinberg et al., 2011) and similarly in the Herodotus Basin (Macgregor, 2011). Some of these sediments arrived from Arabia by a pre-DST drainage system, but most of them arrived from Africa by a proto-Nile drainage system, as indicated by southward thickening trends (Steinberg et al., 2011). First syn-rift sediments in the Red Sea are dated there to the late Eocene-early Oligocene, 35 Ma (Roger et al., 1989 and Watchorn et al., 1998). The eastern arm of the rift system is represented by the Gulf of Aden (Fig. 6b).

Extension occurred in two directions, first $\mathrm{N} 20^{\circ} \mathrm{E}$ and then $\mathrm{N} 160^{\circ} \mathrm{E}$ (Huchon et al., 1991, Lepvrier et al., 2002 and Huchon and Khanbari, 2003). The absolute northward motion of Africa progressively slowed down after $35 \mathrm{Ma}$ (Jolivet and Faccenna, 2000 and Reilinger and McClusky, 2011) while Arabia-Eurasia convergence kept a constant velocity of $\sim 2-3 \mathrm{~cm} / \mathrm{yr}$ with respect to Eurasia from $56 \mathrm{Ma}$ to the present, and Africa-Eurasia convergence slowed down to $\sim 1 \mathrm{~cm} / \mathrm{yr}$ after $\sim 25 \mathrm{Ma}$ once the opening of the Red Sea had started (McQuarrie et al., 2003). 
a

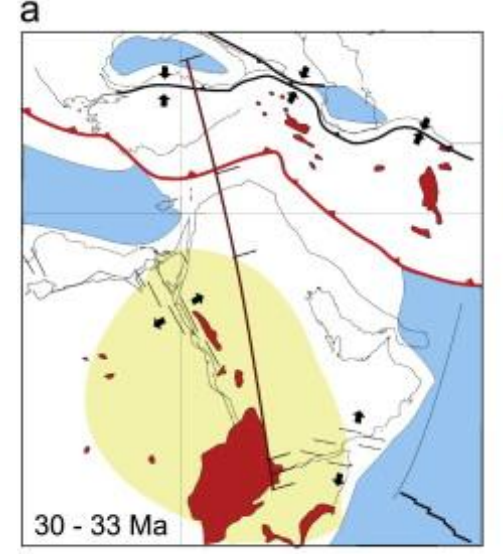

C

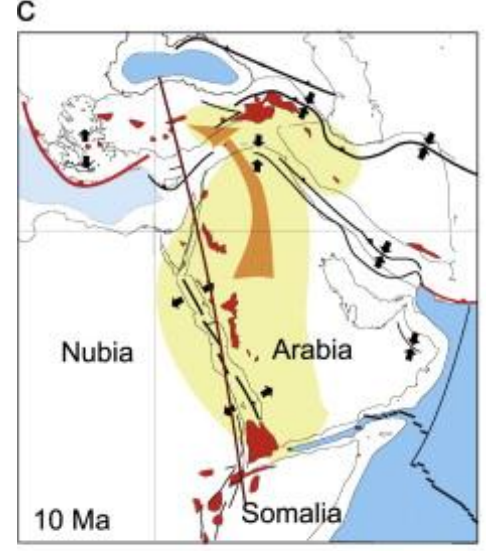

b

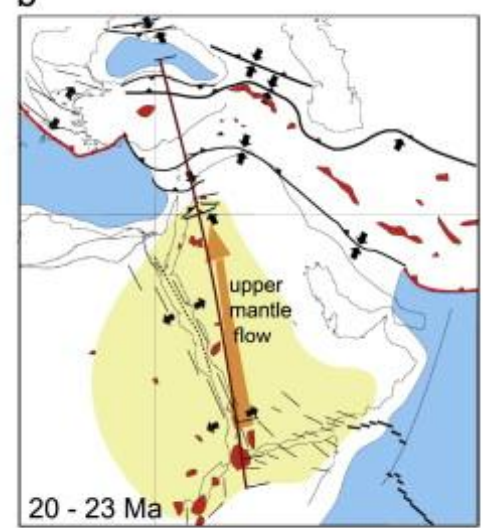

d

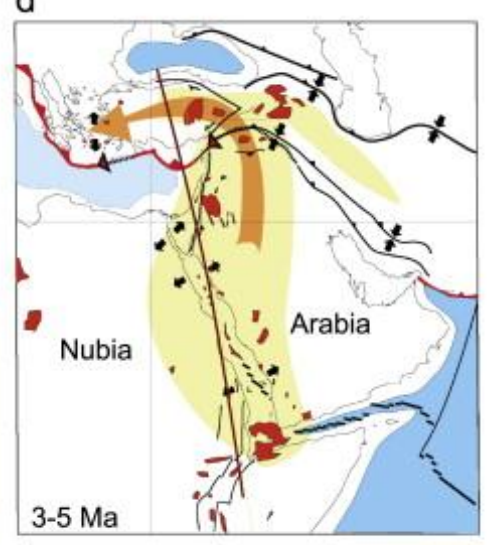

e about $30 \mathrm{Ma}$

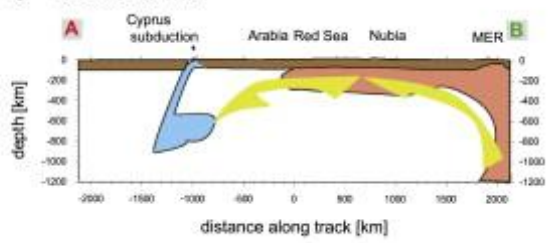

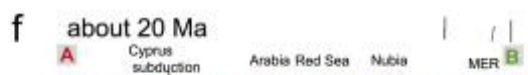
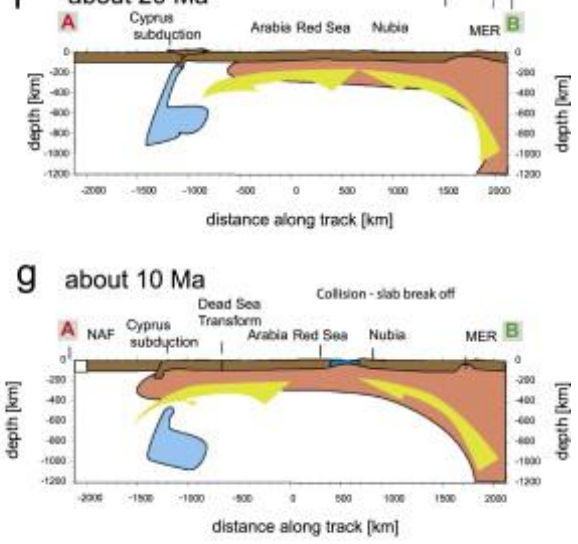

h present day

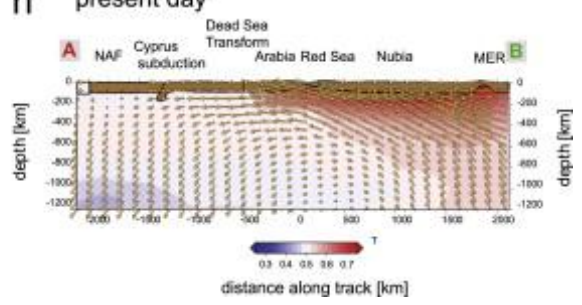

Fig. 6. Tectonic evolution of the AAA system at four stages at 30-33 (a), 20-23 (b), 10-12 (c), and 3$5 \mathrm{Ma}(\mathrm{d})$ and relative, idealized cross sections (e)-(h), cf. Fig. 4 for the present-day. Plate motions are from GPlates (Müller et al., 2008 and Gurnis et al., 2012). Geological features from Barrier and Vrielynck (2010). Red indicates active volcanic fields (undistinguished); blue indicates deep basins; red lines indicate active subduction zone; black lines indicate collisional thrust system; yellowish background area indicate regions under influence of Afar plume; and arrows indicate direction of mantle flow. (For interpretation of the references to color in this figure legend, the reader is referred to the web version of this article.)

The timing of the onset of collision in the Bitlis and Zagros is debated. In Iran, continental subduction and collision initiated around the Oligocene (Jolivet and Faccenna, 2000, Allen and Howard, 2008, Agard et al., 2005, Agard et al., 2011 and McQuarrie and van Hinsbergen, 2013). In the Bitlis, the onset of continental subduction started also as early as Oligocene, but convergence accommodated by subduction in the Bitlis/east Anatolian region did no longer occur after Middle Miocene (Şengör et al., 2003 and Keskin, 2003). This is marked by the final closure Tethyan gateway $\sim 18 \mathrm{Ma}$ (Reuter et al., 2009), the deposition of detritus issued from the Eurasian margin onto Arabia, the cessation of foreland basin deposition (Hüsing et al., 2009), and an increased exhumation of the Bitlis around the mid-late Miocene (Okay et al., 2010). In addition, in Eastern Anatolia last marine deposits date back to the Early Burdigalian ( 12-11 Ma: Gelati, 1975 and Hüsing et al., 2009) whereas in the southern rim of the central Anatolia plateau they post-date the Messinian (Cosentino et al., 2012). Contemporaneously, volcanism started in Arabia at Harrat Ash Shamah (HAS) and in 
Northwest Syria 25 Ma ago (Krienitz et al., 2007 and Krienitz et al., 2009). The occurrence of volcanism at HAS and in NW Syria has been interpreted as due to the arrival of hot material with melting and magma ascent, enhanced by or enhancing crustal extension (Krienitz et al., 2007 and Krienitz et al., 2009).

Around $11 \pm 2 \mathrm{Ma}$, the velocity of Africa slowed down by $~ 50 \%$ for most velocity models (Reilinger and McClusky, 2011) while the motion of Arabia was not strongly perturbed and remained at $\sim 2 \mathrm{~cm} / \mathrm{yr}$ (Burke, 1996, McQuarrie et al., 2003 and Müller et al., 2008).

McQuarrie et al. (2003) and Reilinger and McClusky (2011) described a major reorganization of plate boundaries at $9 \pm 4 \mathrm{Ma}$ (Fig. 6c). At that time, Arabia was fully separated from Africa with the complete opening of the Gulf of Aden (Reilinger and McClusky, 2011). During Miocene times, the activity of the Gulf of Suez decreased, transferred to the Gulf of Aqaba with the consequent formation of the Levant fault, while collisional processes in the Bitlis-Pötürge massif are already well developed. Contemporaneously, another surge of volcanism occurred in Syria in the Aleppo region (Krienitz et al., 2007 and Krienitz et al., 2009) which has been related to asthenosphere upwelling to slab break-off (Keskin, 2003, Keskin, 2007, Krienitz et al., 2009, Şengör et al., 2003 and Şengör et al., 2008). Also, at HAS, it is possible to distinguish between two pulses of effusion (Ilani et al., 2001) that have been attributed to different tectonic causes.

In Eastern Anatolia, the geochemical character of volcanism changed at $\sim 10 \mathrm{Ma}$ from an original calc-alkaline, subduction-related type toward a more alkaline one (Keskin, 2007). In particular, the presence of calc-alkaline volcanism with a distinct subduction signature across Eastern Anatolia has been related to a first episode of slab-steepening event between $\sim 15$ and $10 \mathrm{Ma}$, before slab break off at $10 \mathrm{Ma}$ (Keskin, 2003). This slab steepening episode likely exposed the base of the Eastern Anatolian accretionary complex to asthenospheric temperatures and dragged subduction-related mantle material southward from beneath the Pontides toward the mantle wedge (Keskin, 2003 and Keskin, 2007). Petrological studies also show that the slab steepening episode was likely followed by slab rupture at $\sim 10 \mathrm{Ma}$, resulting in the formation of a slab window. This is attested to the eruption of the first alkaline basanitic lavas in the Eastern Anatolian volcanic province at $\sim 10 \mathrm{Ma}$ (Lebedev et al., 2010) in the north of Lake Van (Keskin et al., 2012c). This implies that enriched and fertile asthenospheric, hotter material once located beneath the slab (i.e., underneath the Arabian continent) moved northward to shallow depths through a slab window (Keskin, 2007), i.e., the convective flow possibly coming from the Afar plume and interacting with the mantle wedge, may be the source of the volcanism across SE Anatolia (Keskin et al., 2012b) (Fig. 6). The North Anatolian Fault probably initiated in east Anatolia ( 10-12 Ma) (Şengör, 1979), propagating westward at $\sim 7-6$ Ma to central Anatolia, and arriving in the Aegean in the Pliocene (Şengör et al., 2005). Keskin et al., 2012a and Keskin et al., 2012b show that the extensive volcanic field of the Karacadağ volcanic area of SE Anatolia was sourced by a garnet-bearing, deep asthenospheric mantle which is similar to that of Afar in terms of its $\mathrm{Sr}$, $\mathrm{Nd}$, and $\mathrm{Pb}$ isotopic ratios (Fig. 7). 


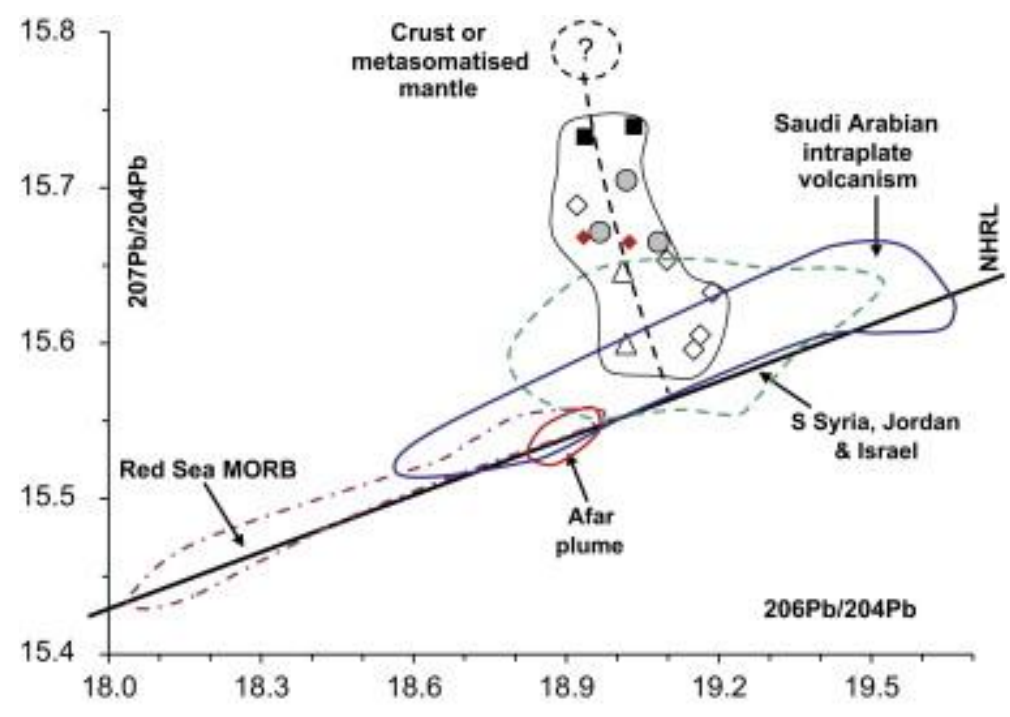

Fig. 7. Geochemical isotope diagram for ${ }^{206} \mathrm{~Pb} /{ }^{204} \mathrm{~Pb}$ versus ${ }^{207} \mathrm{~Pb} /{ }^{204} \mathrm{~Pb}$ for the lavas of the Karacadag neovolcanic area (data from Keskin et al. (2012b)). Data source for the fields drawn in this diagram are listed in Ma et al. (2011), except for two basaltic samples from the Erzurum-Kars Plateau (i.e. EKP in the legend) which are from Keskin et al. (1998) Legend for the Karacadağ lavas. Black squares: Early Stage (Siverek) lavas, Grey circles: Plateau stage lavas, White diamonds: Middle Stage lavas, White triangles: Late Stage (Ovabağ) lavas. Red diamonds: collision-related basalts from the Erzurum-Kars Plateau in the north.

The evolution of the volcanic system displays a progressive decrease in the degree of involvement of a shallow, subcontinental lithospheric mantle source toward a deeper, asthenospheric one, with isotopic composition transitional between Red Sea MORB and Afar plume (Keskin et al., 2012b). From the Pliocene onward, widespread volcanism occurred in Syria along the Dead Sea Fault but also at HAS, NW and NE Syria, and SE Turkey (e.g. Karacadağ: Lustrino et al., 2010, Lustrino et al., 2012, Keskin et al., 2012a, Keskin et al., 2012b and Ekici et al., 2012) contemporaneous with the activity of large volcanic fields along the Red Sea coast (e.g., Giannérini et al., 1988) and during the emplacement of ocean floor in the Red Sea (Girdler, 1991). At HAS, effusion rates are similar to Ethiopia (Hofmann et al., 1997), with $700 \mathrm{~m}$ thick of plateau basalts erupted in less than $1 \mathrm{Ma}$ (Krienitz et al., 2009). As for Karacadağ, the HAS intraplate volcanic is also derived from a mixed lithosphereasthenosphere source, activated by lithosphere extension (Shaw et al., 2003).

The similarities in isotopic composition between the lavas of the Afar region and those of the Arabian province and the expected increase of the mantle temperature during the diffuse phase of volcanism has been related to a sub-lithosphere source related to the Afar plume (Camp and Roobol, 1992, Krienitz et al., 2007 and Krienitz et al., 2009), supporting a model of northward directed mantle flow (Ershov and Nikishin, 2004 and Yarmolyuk et al., 2004) that at $\sim 10$ Ma reached the Eastern Anatolian Collision Zone after the slab steepening and breakoff (Keskin, 2003, Keskin, 2007 and Keskin et al., 2012c). The temporal increase in the alkalinity coupled with a gradual decrease in the subduction component starting at around $10 \mathrm{Ma}$ in the collision-related volcanic units of Eastern Anatolia supports this interpretation (Keskin et al., 2012c). 


\section{Discussion: geodynamic evolution of the AAA system}

In the context of geological and geophysical constraints on the tectonic history of the region, our geodynamic modeling results indicate that the upwelling mantle underneath Afar, the separation of Arabia from Africa and its northward fast drift, the westward escape of Anatolia, and backarc extension in the Aegean may all be the result of the progressive evolution of the Tethyan convection cell (Fig. 6 and Fig. 8).

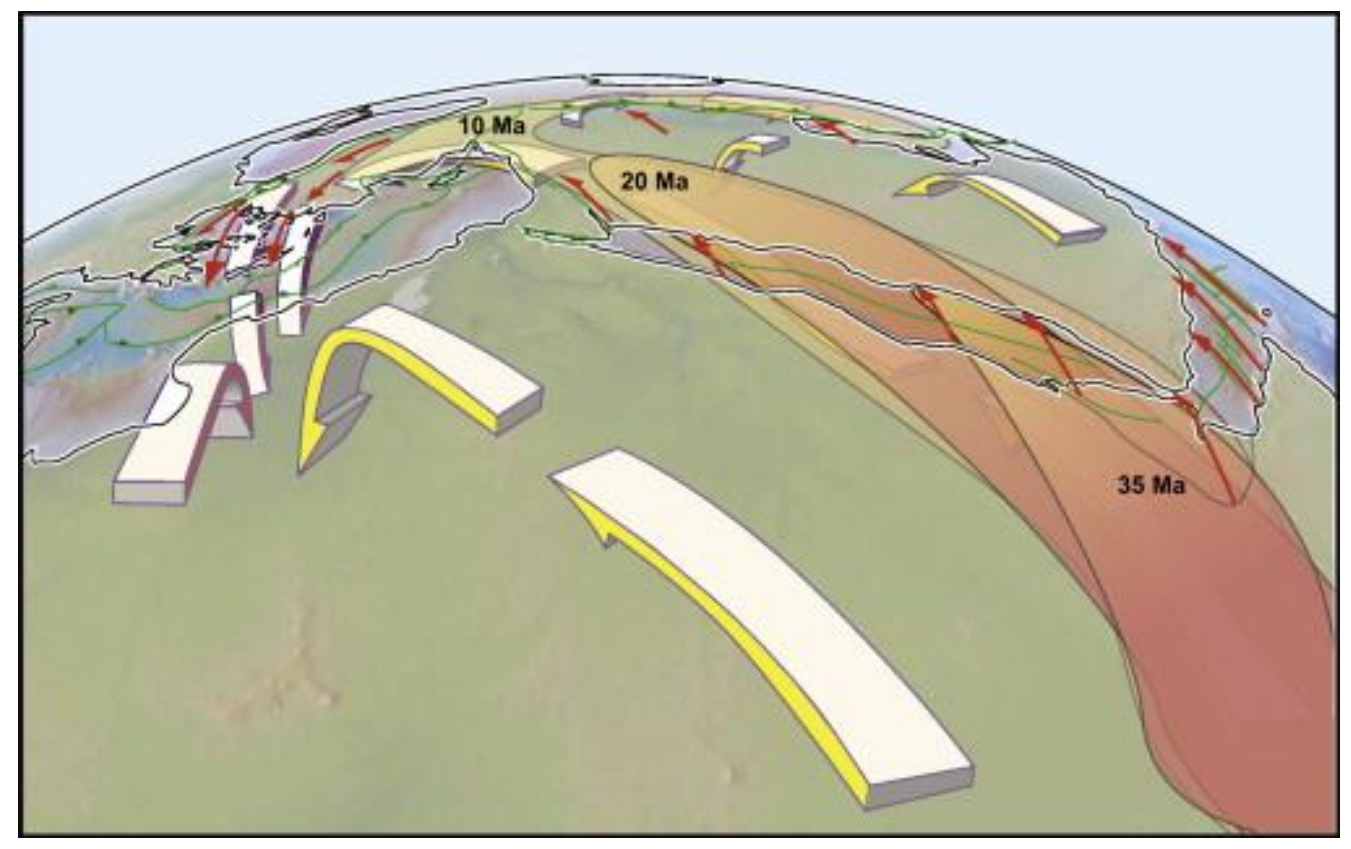

Fig. 8. Conceptual cartoon of mantle flow in the AAA system as inferred from our analysis of geological and geophysical models.

\subsection{Combined effects of an upwelling in Afar and subduction in the Hellenic drag Arabia toward collision}

The upwelling in the Afar likely commenced at 40 Ma, but massive volcanic outpouring and the formation of a large igneous province is dated at $\sim 30 \mathrm{Ma}$. The volcanic record shows that magmatism propagated northward from Ethiopia-Yemen toward the Arabia-Anatolia collisional zone. The spatio-temporal distribution of volcanism, and the similarities of the isotopic compositions of the late stage lavas, suggest that the origin of these melts is most likely related to a sub-lithosphere source resembling the one erupted in Arabia, and connected with the increased temperature due to the emplacement of the Afar plume (Krienitz et al., 2009). The isotopic signature of the Afar plume can be traced up to the Karacadag neovolcanic area on the northernmost part of the Arabian continent in Turkey (Fig. 7).

Those data then support a model of northward directed mantle flow (Ershov and Nikishin, 2004 and Yarmolyuk et al., 2004), channeling the Afar plume head beneath Arabia (Camp and Roobol, 1992, Ebinger and Sleep, 1998 and Hansen et al., 2006) and further north beneath Eastern Anatolia after slab breakoff (Keskin, 2007). Ebinger and Sleep (1998) proposed that rifts may represent natural channels for hot material from mantle plumes to flow horizontally beneath thin lithosphere. Ershov and Nikishin (2004) argue that the 
lithosphere is relatively thin along a south-north line extending from Afar to Anatolia due to a previous orogenic event. Alternatively, Chang and Van der Lee (2011) suggested that the low velocity anomaly beneath the Middle East is distinct from the Afar one and is rooted in the lower mantle. However, other tomography models indicate that the slow velocity beneath Arabia is limited to the upper mantle (Figs. 2 and S1). For example, Hansen et al. (2012) find that the Arabia low velocity zone is connected to the Afar plume in the upper mantle, eventually connecting down to the lower mantle African low shear wave velocity anomaly. We consider this single plume scenario the simpler explanation of deep mantle structure, on which local complexities and volcanic trends may well be superimposed.

Shear-wave splitting and tomographic results of Hansen et al. (2006) and Park et al., 2007 and Park et al., 2008 and the simplified models of Ershov and Nikishin (2004) suggest channeled, horizontal mantle flow from the Afar hotspot. Our modeling substantiates these suggestions and shows that shear wave splitting and mantle anisotropy below Arabia can be fit best when introducing a low viscosity zone, running along the Red Sea, which would channel hot mantle material northward. The spatio-temporal distribution of within-plate alkaline volcanism in Arabia also suggests that the deep source migrated northward from Yemen (31 Ma) to northern Syria (19 Ma) at a high, average speed of $\sim 22 \mathrm{~cm} / \mathrm{yr}$ (Krienitz et al., 2009) even though this estimate could be significantly reduced by considering a larger initial extent of the Afar plume (Ebinger and Sleep, 1998). Our computations show that the velocity of sub-lithosphere material can reach $\sim 10-20 \mathrm{~cm} / \mathrm{yr}$ for some models that account for a low viscosity asthenosphere, or temperature dependent viscosity, and this asthenospheric flow could be even faster if channeled along the NS corridor.

Our flow computations also show that the Afar-Arabia upwellings drive Arabia northward, while dynamically tilting the entire plate toward the Persian Gulf (Daradich et al., 2003). The asthenospheric mantle is "leading the plate," and the present collision with Eurasia is inferred to be driven by a mantle "conveyor belt" (Becker and Faccenna, 2011). The steady, $\sim 2 \mathrm{~cm} / \mathrm{yr}$ northward motion of Arabia prior and after its separation with Africa has been taken as an indication of the role of slab-pull from the Zagros-Bitlis to move the plate northward (Reilinger and McClusky, 2011). Conversely, we take the relatively constant plate speed, irrespective of the collision and break-off episodes (e.g. Keskin, 2003, Keskin, 2007, Şengör et al., 2003, Şengör et al., 2008 and Faccenna et al., 2006), as a sign that other forces rather than slab-pull drive Arabia northward. We conclude that mantle upwellings in the AfarArabia first separated Arabia from Africa, and then propelled Arabia northward with respect to Eurasia protracting its indenting action even after collision.

Arabia then rotated counter-clockwise as a consequence of the asymmetric conditions imposed by the new plate boundary geometry, as suggested in Jolivet and Faccenna (2000) and Bellahsen et al. (2003). The possible impact of the Afar upwelling on the Africa motion is more difficult to predict and further modeling is required.

\subsection{Downwelling system in the Aegean and the extensional system}

Subduction in the Aegean-Tethyan system extended from the Mediterranean to Asia (van der Voo et al., 1999), but the timing of the tectonic evolution of the Tethyan margin appears to also reflect temporal fluctuations in mantle upwellings, encouraging the view of a coupled system. In the Aegean, the penetration of a slab into the lower mantle occurred probably around 50-40 Ma (Faccenna et al., 2003, Capitanio et al., 2009 and van der Meer et al., 2010). This episode is then contemporaneous with the large-scale east Africa upwelling 
( 40-45 Ma Ebinger and Sleep, 1998). This suggests that those two processes are linked, indicating that the onset of a large-scale, whole mantle convection cell (Becker and Faccenna, 2011 and Faccenna et al., 2013).

Subduction in the Aegean exerts a first order control on the evolution of the AAA system. The efficiency of slab pull on the Middle East system is illustrated by the model where only slab pull is at work, matching shearing deformation in the mantle as revealed by seismic anisotropy (Fig. 3a). Geological data show that back-arc extension in the area commenced at 30 Ma (Jolivet and Faccenna, 2000; Jolivet et al., 2013) even though slower extension in the Rhodope region could have started earlier (Brun and Sokoutis, 2007). The total amount of extension in the Aegean has been estimated to be of the order of 300-400 km (Faccenna et al., 2003 and Brun and Sokoutis, 2007; Jolivet et al., 2012). Paleomagnetic data show that the present day curvature of the Aegean arc occurred mainly after $15 \mathrm{Ma}$, indicating that extensional rate accelerates with time (e.g. van Hinsbergen and Schmid, 2012, with references therein).

\subsection{The interaction between mantle upwelling and collisional processes}

Efficient subduction, under the influence of vigorous slab pull, does not favor collision when the trench is moving backward (Molnar and Atwater, 1979; Faccenna et al., 2013). The trench northeast of Arabia is, however, moving northward with respect to Eurasia, indenting the overriding plate (e.g., Barrier and Vrielynck, 2010). This advancing motion of the trench can be favoured by the entrance of continental lithosphere in the subduction zone (Bellahsen et al., 2003), although numerical models suggested that this motion is limited to less than $\sim 100 \mathrm{~km}$ (Magni et al., 2012). The Bitlis convergence zone advanced toward the upper plate by some hundreds of kilometers during the last $25 \mathrm{Ma}$ (Barrier and Vrielynck, 2010). This cannot be easily reconciled with the entrance of continental material alone, and an extra push force related to mantle drag is thus required. The onset of continental subduction probably occurred in the Oligocene (e.g., Barrier and Vrielynck, 2010). Remarkably, only a few hundreds of kilometers south of the collision zone, effusion of alkali basalts was taking place some $10 \mathrm{Ma}$ later while the collision process was ongoing (Fig. 6). The proximity of these two contrasting processes suggests local interactions between mantle upwellings and collision. The orogenic build up as revealed by rapid exhumation and continental stratigraphy (Okay et al., 2010) occurred in the late early Miocene ( 18-13 Ma). Tomographic images and volcanological evolution reveals that the slab is broken beneath the Bitlis suture zone (Faccenna et al., 2006). It is then possible that the slab first acted as a "sail," advancing northward under the action of the flowing mantle and was then eroded and perhaps segmented, facilitated by a thermal, weakening effect of the plume, which then allowed for the entrance of mantle material within the Mediterranean region (Fig. 6) (Keskin, 2007).

\subsection{Collision, Anatolia motion and Aegean extension}

One of the main geodynamic problems of the Middle East is represented by the escape of Anatolia. This motion probably initiated during the Late Miocene, from $\sim 10$ to $12 \mathrm{Ma}$ with a progressive localization of the North Anatolian Fault at 5-6 Ma and onward (Şengör et al., 2005 and Faccenna et al., 2006), when both collision in the Bitlis mountains and backarc extension in the Aegean were well under way. The lateral escape of Anatolia probably occurred contemporaneously with the rise up of the plateau, which in Central Anatolia occurred after $\sim 6 \mathrm{Ma}$ (Cosentino et al., 2012), while in eastern Anatolia it could have started earlier after $\sim 12 \mathrm{Ma}$ (Gelati, 1975). Our results show that more than $\sim 50 \%$ of the motion of 
Anatolia is explained by the upwelling beneath Arabia-Middle East. As shown in the cross sections in Fig. 6, for this flow to be efficient in Anatolia or Aegean, it has to bypass the subduction system plunging northward. The formation of a slab window, probably at $\sim 8$ $10 \mathrm{Ma}$ and progressively enlarging westward (Faccenna et al., 2006 and Cosentino et al., 2012) could have been favoured by the arrival of hot material from Arabia towards the collision zone (Keskin, 2007). Volcanism and uplift over the Anatolia plateau attests to the arrival of hot material in the system in the Pliocene. Previous models suggest that those features result from delamination (Göğüş and Pysklywec, 2008 and Göğüş et al., 2011) and/or slab break off (Keskin, 2003, Keskin, 2007, Şengör et al., 2003 and Şengör et al., 2008) with progressive westward propagation of slab window (Faccenna et al., 2006 and Cosentino et al., 2012). Our model suggests that those fauters can be triggered by the arrival of hot material. More specific geochemical and volcanological studies are needed to test for this model. If this scenario is true, we are facing the evolution of a convection cell that was originally invaded by the hot-upwelling material because the downwelling branch of the cell below Bitlis vanished due to the closure of the oceanic basin.

None of our models fully match the complexity of the region as attested to by non-isostatic topography, surface velocities, and the complex patterns of seismic anisotropy (Fig. 5), and further adjustments of models may yield locally refined dynamic scenarios. However, our models provide a robust, first order view on the dynamics of the system, where the coupling between upwelling mantle in the Afar-Arabia system and the downwelling of the AegeanTethyan slab can generate the general patterns of deformation observed at the surface.

\section{Conclusion}

We reconstruct the patterns of mantle convection beneath the Afar-Anatolia-Aegean system and compare our present-day results to geodetically measured crustal motions and constraints from seismic anisotropy. Our mantle flow models highlight the importance of coupling the pull exerted by the Hellenic slab with the upwelling below Afar-Arabia; this explains the northward indenter motion of Arabia, the northward progression of volcanism along Arabia, the dynamic uplift of Anatolia, its westward motion, and the Aegean extension in a single convection system, established episodically over the last $\sim 40 \mathrm{Ma}$.

Jointly interpreting the present-day geodynamic models with geological constraints, we suggest that it may be possible to backtrack the geometry and interactions of the AAA lithosphere-mantle system throughout the Tertiary. The upwelling material associated with the deep mantle Africa-Afar plume flowed northward in the asthenosphere during the closure of the ocean, assisted in continental breakup, and propelled Arabia to induce collision. Several slab segmentation episodes might have opened mantle flow windows, facilitating plume northward transport. Eventually, this lead to asthenospheric flow inside the Aegean region, and accelerating of the Hellenic backarc extension to the rates we see today. Our findings emphasize the role of the deep mantle in affecting microplate motions and controlling the geological expression of upper mantle convection.

\section{Acknowledgments}

Discussions with Zohar Gvirtzman and Jean Pierre Brun con- tributed to clarify some of the concepts expressed here. We thank the reviewer D. Van Hinsbergen and the editor Y. Ricard for the useful comments on the manuscript, CitcomS authors including S. Zhong, E. Tan, A. McNamara, and L. Moresi for their contributions, CIG (geodynamics.org), E. Kaminski for 
sharing DREX, and all seismologists who share their tomographic models and shear wave splitting measurements in electronic form. Computations were performed on USC's High Performance Computing Center, and research was partially supported by the NSF Grants EAR-0809023 and EAR-0643365. M. Keskin thanks to TUBITAK for their support (Project no. 108Y222).

\section{References}

P. Agard, J. Omrani, L. Jolivet, F. Mouthereau

Convergence history across Zagros (Iran): constraints from collisional and earlier deformation

Int. J. Earth Sci., 94 (2005), pp. 401-419

P. Agard, J. Omrani, L. Jolivet, H. Whitechurch, B. Vrielynck, W. Spakman, P. Monié, B. Meyer, R. Wortel

Zagros orogeny: a subduction-dominated process

Geol. Mag., 148 (2011), pp. 1-34

M.B. Allen, H.A. Armstrong

Arabia-Eurasia collision and the forcing of mid-Cenozoic global cooling

Palaeogeogr. Palaeoclimatol. Palaeoecol., 265 (2008), pp. 52-58

W. Alvarez

Protracted continental collisions argue for continental plates driven by basal traction

Earth Planet. Sci. Lett., 296 (2010), pp. 434-442

A. ArRajehi, S. McClusky, R. Reilinger, M. Daoud, A. Alchalbi, S. Ergintav, F. Gomez, J. Sholan, F. Bou-Rabee, G. Ogubazghi, B. Haileab, S. Fisseha, L. Asfaw, S. Mahmoud, A. Rayan, R. Bendik, L. Kogan

Geodetic constraints on present day motion of the Arabian Plate: implications for Red Sea and Gulf of Aden rifting

Tectonics, 29 (2010), p. TC3011 http://dx.doi.org/10.1029/2009TC002482

Y. Avni, A. Segev, H. Ginat

Oligocene regional denudation of the northern Afar dome: pre- and syn-breakup stages of the Afro-Arabian plate

Geol. Soc. Am. Bull., 124 (11-12) (2012), pp. 1871-1897

http://dx.doi.org/10.1130/B30634.1

Barrier, E., Vrielynck, B., 2010. Palaetectonic Map of the Midlle East. Middle East Basin Evolution Programme. Scale 1/18 500000.

C. Bassin, G. Laske, G. Masters

Current limits of resolution for surface wave tomography in North America

Eos Trans. Am. Geophys. Union, 81 (2000), p. F897 
I.D. Bastow et al.

Upper mantle seismic structure beneath the Ethiopian hot spot: rifting at the edge of the African low-velocity anomaly

Geochem. Geophys. Geosyst., 9 (2008), p. Q12022

I. Bastow, G. Stuart, J.-M. Kendall, C. Ebinger

Upper-mantle seismic structure in a region of incipient continental breakup:

northern Ethiopian rift

Geophys. J. Int., 162 (2) (2005), pp. 479-493

H.J. Bayer, G. HoÅstzl, A.R. Jado, B. Roscher, W. Voggenreiter

Sedimentary and structural evolution of the northwest Arabian Red Sea margin

Tectonophysics, 153 (1998), pp. 137-151

T.W. Becker

On the effect of temperature and strain-rate dependent viscosity on global mantle flow, net rotation, and driving forces

Geophys. J. Int., 167 (2006), pp. 943-957

T.W. Becker, C. Faccenna

Mantle conveyor beneath the Tethyan collisional belt

Earth Planet. Sci. Lett., 310 (2011), pp. 453-461

T.W. Becker, R.J. O'Connell

Predicting plate velocities with geodynamic models

Geochem. Geophys. Geosyst., 2 (2001), p. 12

T.W. Becker, S. Chevrot, V. Schulte-Pelkum, D.K. Blackman

Statistical properties of seismic anisotropy predicted by upper mantle geodynamic models

J. Geophys. Res., 111 (2006), p. B08309 http://dx.doi.org/10.1029/2005JB004095

T.W. Becker, V. Schulte-Pelkum, D.K. Blackman, J.B. Kellogg, R.J. O'Connell

Mantle flow under the western United States from shear wave splitting

Earth Planet. Sci. Lett., 247 (2006), pp. 235-251

T.W. Becker, L. Boschi

A comparison of tomographic and geodynamic mantle models

Geochem. Geophys. Geosyst., 3 (2002) http://dx.doi.org/10.1029/2001GC000168

N. Bellahsen, C. Faccenna, F. Funiciello, J.M. Daniel, L. Jolivet

Why did Africa separate from Africa? Insight from 3D laboratory experiments

Earth Planet. Sci. Lett., 216 (2003), pp. 365-381

M. Benoit, A. Nyblade, J. VanDecar

Upper mantle P wavespeed variations beneath Ethiopia and the origin of the Afar hotspot

Geology, 34 (5) (2006), pp. 329-332

H. Bijwaard, W. Spakman, E. Engdahl

Closing the gap between regional and global travel time tomography

J. Geophys. Res., 103 (1998), pp. 30055-30078 
P. Bird

An updated digital model of plate boundaries

Geochem. Geophys. Geosyst., 4 (3) (2003), p. 1027

C.B. Biryol, G. Zandt, S.L. Beck, A.A. Özacar, H.E. Adiyaman, R.C. Gans

Shear wave splitting along a nascent plate boundary: the North Anatolian Fault

Zone

Geophys. J. Int., 181 (2010), pp. 1201-1213

C.B. Biryol, S.L. Beck, G. Zandt, A.A. Özacar

Segmented African lithosphere beneath the Anatolian region inferred from teleseismic P-wave tomography

Geophys. J. Int., 184 (2011), pp. 1037-1057

L. Boschi, C. Faccenna, T.W. Becker

Mantle structure and dynamic topography in the Mediterranean Basin

Geophys. Res. Lett., 37 (2010), p. L20303

W. Bosworth, P. Huchon, K. McClay

The Red Sea and Gulf of Aden Basins

J. Afr. Earth Sci., 43 (2005), pp. 334-378

J.P. Brun, D. Sokoutis

Kinematics of the Southern Rhodope core complex (North Greece)

Int. J. Earth Sci., 96 (2007), pp. 1079-1099 http://dx.doi.org/10.1007/s00531-007-

$\underline{0174-2}$

K. Burke

The African Plate

S. Afr. J. Geol., 99 (1996), pp. 341-409

V.E. Camp, M.J. Roobol

Upwelling asthenosphere beneath western Arabia and its regional implications

J. Geophys. Res., 97 (1992), pp. 15255-15271

http://dx.doi.org/10.1029/92JB00943

F.A. Capitanio, C. Faccenna, R. Funiciello

The opening of Sirte basin: result of slab avalanching?

Earth Planet. Sci. Lett., 285 (2009), pp. 210-216

S.-J. Chang, S. van der Lee, M.P. Flanagan, H. Bedle, F. Marone, E.M. Matzel, M.E.

Pasyanos, A.J. Rodgers, B. Romanowicz, C. Schmid

Joint inversion for three-dimensional S velocity mantle structure along the Tethyan margin

J. Geophys. Res., 115 (2010), p. B08309 http://dx.doi.org/10.1029/2009JB007204

S.-J. Chang, S. Van der Lee

Mantle plumes and associated flow beneath Arabia and East Africa

Earth Planet. Sci. Lett., 302 (2011), pp. 448-454

http://dx.doi.org/10.1016/j.eps1.2010.12.050 
S.-J. Chang, M. Merino, S. Van der Lee, S. Stein, C.A. Stein

Mantle flow beneath Arabia offset from the opening Red Sea

Geophys. Res. Lett., 38 (2011), p. L04301

http://dx.doi.org/10.1029/2010GL045852

C.P. Conrad, C. Lithgow-Bertelloni

How mantle slabs drive plate tectonics

Science, 298 (2002), pp. 207-209

D. Cosentino, T.F. Schildgen, P. Cipollari et al.

Late Miocene surface uplift of the southern margin of the Central Anatolian

Plateau, Central Taurides, Turkey

Geol. Soc. Am. Bull., 124 (1-2) (2012), pp. 133-145

T.J. Craig, J.A. Jackson, K. Priestley, D.M. McKenzie

Earthquake distribution pattern in Africa: their relationship to variation in

lithospheric and geological structure, and their rheological implications

Geophys. J. Int., 185 (2011), pp. 403-434

A. Daradich, J.X. Mitrovica, R.N. Pysklywec, S.D. Willett, A.M. Forte

Mantle flow, dynamic topography, and rift-flank uplift of Arabia

Geology, 31 (2003), pp. 901-904

C. DeMets, R.G. Gordon, D.F. Argus, S. Stein

Effect of recent revisions to the geomagnetic reversal time scale on estimates of current plate motions

Geophys. Res. Lett., 21 (1994), pp. 2191-2194

J. Dercourt et al.

Geological evolution of the Tethys belt from the Atlantic to the Pamirs since the Lias

Tectonophysics, 123 (1986), pp. 241-315

C.J. Ebinger, N.H. Sleep

Cenozoic magmatism throughout east Africa resulting from impact of a single plume

Nature, 395 (1998), pp. 788-791

C.J. Ebinger, T. Yemane, G. Wolde Gabriel, J. Aronson

Late Eocene-Recent volcanism and faulting in the southern Main Ethiopian rift system

J. Geol. Soc. London, 150 (1993), pp. 99-108

T. Ekici, C.G. Macpherson, N. Otlu

Polybaric melting of a single mantle source during the Neogene Siverek phase of the Karacadağ Volcanic Complex, SE Turkey

Lithos, 146-147 (2012), pp. 152-163

E.R. Engdahl, R.D. van der Hilst, R. Buland

Global teleseismic earthquake relocation with improved travel times and procedures for depth determination

Bull. Seismol. Soc. Am., 88 (1998), pp. 722-743 
A.V. Ershov, A.M. Nikishin

Recent geodynamics of the Caucasus-Arabia-East Africa Region

Geotectonics, Engl. Transl., 38 (2) (2004), pp. 123-136

C. Faccenna, O. Bellier, J. Martinod, C. Piromallo, V. Regard

Slab detachment beneath eastern Anatolia: a possible cause for the formation of the North Anatolian fault

Earth Planet. Sci. Lett., 242 (2006), pp. 85-97

C. Faccenna, L. Jolivet, C. Piromallo, A. Morelli

Subduction and the depth of convection in the Mediterranean mantle

J. Geophys. Res., 108 (B2) (2003), p. 2099

C. Faccenna, T.W. Becker

Shaping mobile belt from small scale convection

Nature (2010), p. 465 http://dx.doi.org/10.1038/nature09064

C. Faccenna, T.W. Becker, C. Conrad, L. Husson

Mountain building and mantle dynamics

Tectonics, 32 (2013), pp. 82-93 http://dx.doi.org/10.1029/2012TC003176

A.M. Forte

Constraints on seismic models from other disciplines-implications for mantle dynamics and composition

G. Schubert, D. Bercovici (Eds.), Treatise on Geophysics, Elsevier, Amsterdam (2007), pp. 805-858

A.M. Forte, S. Quéré, R. Moucha, N.A. Simmons, S.P. Grand, J.X. Mitrovica, D.B. Rowley

Joint seismic-geodynamic-mineral physical modelling of African geodynamics: a reconciliation of deep-mantle convection with surface geophysical constraints Earth Planet. Sci. Lett., 295 (2010), pp. 329-341

Z. Garfunkel, A. Horowitz

The upper tertiary and quaternary morphology of the Negev, Israel

Isr. J. Earth Sci., 15 (1966), pp. 101-117

Z. Garfunkel, M. Beyth

Constraints on the structural development of Afar imposed by the kinematics of the major surrounding plates

G. Yirgu, C.J. Ebinger, P.K.H. Maguire (Eds.), The Afar Volcanic Province Within the East African Rift System, vol. 259Geological Society of London, Special Publication (2006), pp. 23-42 
E.M. Gashawbeza, S.L. Klemperer, A.A. Nyblade, K.T. Walker, K.M. Keranen Shear-wave splitting in Ethiopia: Precambrian mantle anisotropy locally modified by Neogene rifting

Geophys. Res. Lett., 31 (2004), p. L18602

R. Gelati

Miocene marine sequence from Lake Van: Eastern Turkey

Riv. Ital. Paleontol. Stratigr., 81 (1975), pp. 477-490

W. Ghebreab

Tectonics of the Red Sea region reassessed

Earth Sci. Rev., 45 (1998), pp. 1-44

A. Ghosh, T.W. Becker, S. Zhong

Effects of lateral viscosity variations on the geoid

Geophys. Res. Lett., 37 (2010), p. L01301

G. Giannérini, R. Campredon, G. Féraud, B. Abou Zakhem

Déformations intraplaques et volcanisme associé: example de la bordure NW de la plaque Arabique au Cénozoique

Bull. Soc. Géol. France IV, 6 (1988), pp. 937-947

R.W. Girdler

The Afro-Arabian rift system - an overview

Tectonophysics, 197 (1991), pp. 139-153

O.H. Göğüş, R.N. Pysklywec

Mantle lithosphere delamination driving plateau uplift and synconvergent extension in eastern Anatolia

Geology, 36 (2008), pp. 723-726 http://dx.doi.org/10.1130/G24982A.1

O.H. Göğüş, R.N. Pysklywec, F. Corbi, C. Faccenna

The surface tectonics of mantle lithosphere delamination following ocean lithosphere subduction: insights from physical-scaled analogue experiments

Geochem. Geophys. Geosyst., 12 (2011), p. Q05004

http://dx.doi.org/10.1029/2010GC003430

S.P. Grand

Mantle shear wave tomography and the fate of subducted slabs

Philos. Trans. R. Soc. London Ser. A, 360 (2002), pp. 2475-2491

O. Gudmundsson, M. Sambridge

A regionalized upper mantle (RUM) seismic model

J. Geophys. Res., 103 (1998), pp. 7121-7136

M. Gurnis, J.X. Mitrovica, J. Ritsema, H.-J. van Heijst

Constraining mantle density structure using geological evidence of surface uplift rates: the case of the African superplume

Geochem. Geophys. Geosyst., 1 (2000) 
M. Gurnis, M. Turner, S. Zahirovic, L. DiCaprio, S. Spasojevic, R.D. Müller, J. Boyden, M. Seton, V.C. Manea, D.J. Bower

Plate tectonic reconstructions with continuously closing plates

Comput. Geosci., 38 (2012), pp. 35-42

Z. Gvirtzman, J. Steinberg, J. Bar, B. Buchbinder, B. Zilberman, R. Siman-Tov, R. Calvo, L. Grossowicz, A. Almogi-Labin, E. Rosensaft, M.

Retreating Late Tertiary shorelines in Israel: implications for the exposure of north Arabia and Levant during Neotethys closure

Lithosphere, 3 (2) (2011), pp. 95-109

E. Hafkenscheid, M.J.R. Wortel, W. Spakman

Subduction history of the Tethyan region derived from seismic tomography and tectonic reconstructions

J. Geophys. Res., 111 (2006), p. B08401 http://dx.doi.org/10.1029/2005JB003791

B.H. Hager, R.W. Clayton

Constraints on the structure of mantle convection using seismic observations, flow models, and the geoid

R.W. Peltier (Ed.), Mantle Convection; Plate Tectonics and Global Dynamics,

Gordon and Breach Science Publishers, New York (1989), pp. 657-763

B.H. Hager

Subducted slabs and the geoid: constraints on mantle rheology and flow

J. Geophys. Res., 89 (1984), pp. 6003-6015

S. Hansen, S. Schwartz, A. Al-Amri, A. Rodgers

Combined plate motion and density driven flow in the asthenosphere beneath

Saudi Arabia: evidence from shear-wave splitting and seismic anisotropy

Geology, 34 (10) (2006), pp. 869-872

S.E. Hansen, A.A. Nyblade, M.H. Benoit

Mantle structure beneath Africa and Arabia from adaptively parameterized P-wave tomography: implications for the origin of Cenozoic Afro-Arabian tectonism

Earth Planet. Sci. Lett., 319-320 (2012), pp. 23-34

C. Hofmann, V. Courtillot, G. Féraud, P. Rochette, G. Yirgu, E. Ketefo, R. Pik

Timing of the Ethiopian flood basalt event and implications for plume birth and global change

Nature, 389 (1997), pp. 838-841

P. Huchon, K. Khanbari

Rotation of the syn-rift stress Åeeld of the northern Gulf of Aden margin, Yemen Tectonophysics, 364 (2003), pp. 147-166

P. Huchon, F. Jestin, J.M. Cantagrel, J.M. Gaulier, S.A. Khirbash, A. Gafaneh

Extensional deformation in Yemen since Oligocene and the Africa-Arabia-

Somalia triple junction

Ann. Tectonicae, 5 (1991), pp. 141-163 
S.K. Hüsing, W.J. Zachariasse, D.J.J. Van Hinsbergen, W. Krijgsman, M. Inceöz, M. Harzhauser, O. Mandic, A. Kroh

Oligo-Miocene foreland basin evolution in SE Anatolia: implications for the closure of the eastern Tethys gateway

D.J.J. Van Hinsbergen, M.A. Edwards, R. Govers (Eds.), Geodynamics of Collision and Collapse at the Africa-Arabia-Eurasia Subduction Zone, vol. 311Geological Society of London Special Publication (2009), pp. 107-132

L. Husson

Dynamic topography above retreating subduction zones

Geology, 34 (2006), pp. 741-744 http://dx.doi.org/10.1130/G22436.1

S.Y. Ilani, Y. Harlavan, K. Tarawneh, I. Rabba, R. Weinberger, K. Ibrahim, S. Peltz, G. Steinitz

New K-Ar ages of basalts from the Harrat Ash Shaam volcanic field in Jordan: implications for the span and duration of the uppermantle upwelling beneath the western Arabian plate

Geology, 29 (2001), pp. 171-174 http://dx.doi.org/10.1130/0091-7613(2001)029

L. Jolivet, C. Faccenna

Mediterranean extension and the Africa-Eurasia collision

Tectonics, 19 (6) (2000), pp. 1095-1106

L. Jolivet et al.

Aegean tectonics: strain localisation, slab tearing and trench retreat

Tectonophysics, 597-598 (2013), pp. 1-33

E. Kaminski, N.M. Ribe, J.T. Browaeys

D-Rex, a program for calculation of seismic anisotropy due to crystal lattice preferred orientation in the convective upper mantle

Geophys. J. Int., 157 (2004), pp. 1-9

A. Kaviani, D. Hatzfeld, A. Paul, M. Tatar, K. Priestley

Shear-wave splitting, lithospheric anisotropy, and mantle deformation beneath the Arabia-Eurasia collision zone in Iran

Earth Planet. Sci. Lett., 286 (2009), pp. 371-378

M. Keskin, A.V. Chugaev, V.A. Lebedev, E.V. Sharkov, V. Oyan, O. Kavak

Geochronology and origin of mantle sources for Late Cenozoic intraplate volcanism in the frontal part of the Arabian Plate in the Karacadağ Neovolcanic Area of Turkey. Part 1. The results of isotope-geochronologic studies J. Volcanol. Seismol., 6 (2012), pp. 31-42 http://dx.doi.org/10.1134/S0742046312060036

M. Keskin, A.V. Chugaev, V.A. Lebedev, E.V. Sharkov, V. Oyan, O. Kavak Geochronology and origin of mantle sources for Late Cenozoic Intraplate volcanism in the frontal part of the Arabian Plate, in the Karacadağ Neovolcanic Area of Turkey. Part 2. The results of geochemical and isotope $(\mathrm{Sr}-\mathrm{Nd}-\mathrm{Pb})$ studies J. Volcanol. Seismol., 6 (2012), pp. 43-70 http://dx.doi.org/10.1134/S0742046312060048 
Keskin, M., Sharkov, E.V., Lebedev, V.A., Chugaev, A.V., Oyan, V., Genç, Ş.C., Ünal, E., Aysal, N., 2012c. Miocene to recent Magmatism and Geodynamics of Eastern Turkey. European Union of Geosciences.Vienna. Session: TS6.1/GD5.5 The Alpine-Himalayan Convergence Zone: From the Mediterranean to SE Asia. \ http://meetingorganizer.copernicus.org/EGU2012/EGU2012-12748-3.pdf $\rangle$.

M. Keskin

Magma generation by slab steepening and breakoff beneath a subductionaccretion complex: an alternative model for collision-related volcanism in eastern Anatolia, Turkey

Geophys. Res. Lett., 30 (24) (2003), p. 8046

M. Keskin

Eastern Anatolia: a hotspot in a collision zone without a mantle plume G.R. Foulger, D.M. Jurdy (Eds.), Plates, Plumes, and Planetary Processes, vol. 430Geological Society of America Special Paper, AGU (2007), pp. 693-722

M. Keskin, J.A. Pearce, J.G. Mitchell

Volcano-stratigraphy and geochemistry of collision-related volcanism on the Erzurum-Kars Plateau, North Eastern Turkey

J. Volcanol. Geotherm. Res., 85 (1-4) (1998), pp. 355-404

T. Komut, R. Gray, R. Pysklywec, O.H. Göğüş

Mantle flow uplift of western Anatolia and the Aegean: interpretations from geophysical analyses and geodynamic modeling

J. Geophys. Res., 117 (2012), p. B11412 http://dx.doi.org/10.1029/2012JB009306

C Kreemer, N. Chamot-Rooke

Contemporary kinematics of the southern Aegean and the Mediterranean Ridge Geophys. J. Int., 157 (2004), pp. 1377-1392

M.-S. Krienitz, K.M. Haase, K. Mezger, P. van den Bogaard, V. Thiemann, M.A. Shaikh Mashail

Tectonic events, continental intraplate volcanism, and mantle plume activity in northern Arabia: constraints from geochemistry and Ar-Ar dating of Syrian lavas

Geochem. Geophys. Geosyst., 10 (2009) http://dx.doi.org/10.1029/2008GC002254 M.S. Krienitz, K.M. Haase, K. Mezger, M.A. Shaikh-Mashail

Magma genesis and mantle dynamics at the Harrat Ash Shamah Volcanic Field (southern Syria)

J. Petrol., 48 (2007), pp. 1513-1542 http://dx.doi.org/10.1093/petrology/egm028

X. Le Pichon

Land-locked oceanic basins and continental collision: the eastern Mediterranean as a case example

K. Hsu (Ed.), Mountain Building Processes (ed.), Academic, London (1982), pp. 129-146

X. Le Pichon, C. Kreemer

The Miocene-to-Present kinematic evolution of the Eastern Mediterranean and Middle East and its implications for dynamics

Annu. Rev. Earth Planet. Sci., 38 (2010), pp. 323-351 
S. Lebedev, R.D. Van der Hilst

Global upper-mantle tomography with the automated multi-mode surface and $\mathrm{S}$ waveforms

Geophys. J. Int., 173 (3) (2008), pp. 827-843

V.A. Lebedev, E.V. Sharkov, M. Keskin, V. Oyan

Geochronology of the Late Cenozoic volcanism in the area of Van Lake (Turkey): an example of the developmental dynamics for magmatic processes

Dokl. Earth Sci., 2010 (433) (2010), pp. 1031-1037

http://dx.doi.org/10.1134/S1028334×1008009X

J. Lei, D. Zhao

Teleseismic evidence for a break-off subducting slab under Eastern Turkey

Earth Planet. Sci. Lett., 257 (2007), pp. 14-28

C. Lepvrier, M. Fournier, T. Berard, J. Roger

Cenozoic extension in coastal Dhofar (southern Oman): implications on the oblique rifting of the Gulf of Aden

Tectonophysics, 357 (2002), pp. 279-293

C. Li, R.D. van der Hilst, A.S. Meltzer, E.R. Engdahl

Subduction of the Indian lithosphere beneath the Tibetan Plateau and Burma

Earth Planet. Sci. Lett., 274 (2008), pp. 157-168

C. Lithgow-Bertelloni, P.G. Silver

Dynamic topography, plate driving forces and the African superswell

Nature, 395 (1998), pp. 269-272

C. Lithgow-Bertelloni, M.A. Richards

The dynamics of Cenozoic and Mesozoic plate motions

Rev. Geophys., 36 (1998), pp. 27-78

M.D. Long, T.W. Becker

Mantle dynamics and seismic anisotropy

Earth Planet. Sci. Lett., 297 (2010), pp. 341-354

M. Lustrino, M. Keskin, M. Mattioli, O. Kavak

Heterogeneous mantle sources feeding the volcanic activity of Mt. Karacadağ (SE Turkey)

J. Asian Earth Sci., 46 (2012), pp. 120-139

http://dx.doi.org/10.1016/j.jseaes.2011.11.016

M. Lustrino, M. Keskin, M. Mattioli, V.A. Lebedev, A. Chugaev, E. Sharkov, O. Kavak

Early activity of the largest Cenozoic shield volcano in the circum-Mediterranean area: Mt. Karacadağ, SE Turkey

Eur. J. Mineral., 22 (2010), pp. 343-362 http://dx.doi.org/10.1127/0935-

$\underline{1221 / 2010 / 0022-2024}$

G.S.K. Ma, J. Malpas, C. Xenophontos, G.H.N. Chan

Petrogenesis of Latest Miocene-Quaternary Continental IntraplateVolcanism along the Northern Dead Sea Fault System (Al Ghab-Homs Volcanic Field), Western Syria: evidence for lithosphere-asthenosphere interaction J. Petrol., 52 (2) (2011), pp. 401-430 http://dx.doi.org/10.1093/petrology/egq085 V. Magni, J. van Hunen, F. Funiciello, C. Faccenna 
Numerical models of slab migration in continental collision zones

Solid Earth, 3 (2012), pp. 1-14

Macgregor, D., 2011. Rift Shoulder Source to Prodelta Sink: The Cenozoic Development of the Nile Drainage System. Search and Discovery Article \#50506.

N. McQuarrie, J.M. Stock, C. Verdel, B.P. Wernicke

Cenozoic evolution of Neotethys and implications for the causes of plate motions

Geophys. Res. Lett., 30 (2003), p. 2036

N. McQuarrie, D.J.J. van Hinsbergen

Retro-deforming the Arabia-Eurasia collision zone: age of collision versus magnitude of continental subduction

Geology, 41 (2013), pp. 315-318

\section{Mégnin, B. Romanowicz}

The 3D shear velocity structure of the mantle from the inversion of body, surface and higher mode waveforms

Geophys. J. Int., 143 (2000), pp. 709-728

M.S. Miller, T.W. Becker

Mantle flow deflected by interactions between subducted slabs and cratonic keels

Nat. Geosci., 5 (2012), pp. 726-730 http://dx.doi.org/10.1038/ngeo1553

P. Molnar, T. Atwater

Interarc spreading and cordilleran tectonics as alternates related to the age of subducted oceanic lithosphere

Earth Planet. Sci. Lett., 41 (330-340) (1979), p. 1979

R. Montelli, G. Nolet, F.A. Dahlen, G. Masters

A catalogue of deep mantle plumes: new results from finite-frequency tomography Geochem. Geophys. Geosyst., 7111 (2006), p. 2006

R. Moucha, A. Forte

Changes in African topography driven by mantle convection

Nat. Geosci., 4 (10) (2011), pp. 707-712

R.D. Müller, M. Sdrolias, C. Gaina, B. Steinberger, C. Heine

Long-term sea-level fluctuations driven by ocean basin dynamics

Science, 319 (2008), pp. 1357-1362

H-C. Nataf, Y. Ricard

3SMAC: an a priori tomographic model of the upper mantle based on geophysical modeling

Phys. Earth Planet. Inter., 95 (1996), pp. 101-122

A.I. Okay, M. Zattin, W. Cavazza

Apatite fission-track data for the Miocene Arabia-Eurasia collision Geology, 38 (1) (2010), pp. 35-38 
Y. Park, A.A. Nyblade, A. Rodgers, A. Al-Amri

Upper mantle structure beneath the Arabian Peninsula and northern Red Sea from teleseismic body wave tomography: implications for the origin of Cenozoic uplift and volcanism in the Arabian Shield

Geochem. Geophys. Geosyst., 8 (2007), p. Q06021

http://dx.doi.org/10.1029/2006GC001566

Y. Park, A.A. Nyblade, A. Rodgers, A. Al-Amri

$S$ wave velocity structure of the Arabian Shield upper mantle from Rayleigh wave tomography

Geochem. Geophys. Geosyst., 9 (2008), p. Q07020

http://dx.doi.org/10.1029/2007GC001895

R. Pik, B. Marty, J. Carignan, J. Lavé

Stability of the Upper Nile drainage network (Ethiopia) deduced from (U-Th)/He thermochronometry: implications for uplift and erosion of the Afar plume dome Earth Planet. Sci. Lett., 215 (2003), pp. 73-88

C. Piromallo, A. Morelli

$\mathrm{P}$-wave tomography of the mantle under the Alpine-Mediterranean area

J. Geophys. Res., 108 (2003), p. 2065 http://dx.doi.org/10.1029/2002JB001757

R. Reilinger, S. McClusky, P. Vernant, S. Lawrence, S. Ergintav, R. Çakmak, H. Özener, F. Kadirov, I. Guliev, R. Stepanyan, M. Nadariya, G. Hahubia, S. Mahmoud, K. Sakr, A.

ArRajehi, D. Paradissis, A. Al-Aydrus, M. Prilepin, T. Guseva, E. Evren, A. Dmitrotsa, S.V. Filikov, F. Gomez, R. Al-Ghazzi, G. Karam

GPS constraints on continental deformation in the Africa-Arabia-Eurasia continental collision zone and implications for the dynamics of plate interactions J. Geophys. Res., 111 (2006), p. B05411 http://dx.doi.org/10.1029/2005JB004051

R. Reilinger, S. McClusky

Nubia-Arabia-Eurasia plate motions and the dynamics of Mediterranean and Middle East tectonics

Geophys. J. Int., 186 (2011), pp. 971-979

A. Replumaz, H. Karason, R.D. van der Hilst, J. Besse, P. Tapponnier

4-D evolution of SE Asia's mantle from geological reconstructions and seismic tomography

Earth Planet. Sci. Lett., 221 (2004), pp. 103-115

M. Reuter, W.E. Piller, M. Harzhauser, O. Mandic, B. Berning, F. Rogl, A. Kroh, M.-P.

Aubry, U. Wielandt-Schuster, A. Hamedani

The Oligo-/Miocene Qom Formation (Iran): evidence for an early Burdigalian restriction of the Tethyan Seaway and closure of its Iranian gateways

Int. J. Earth Sci. (Geol. Rundsch.), 98 (2009), pp. 627-650

Y. Ricard, C. Vigny

Mantle dynamics with induced plate tectonics

J. Geophys. Res., 94 (1989), pp. 17543-17559

Y. Ricard, L. Fleitout, C. Froidevaux

Geoid heights and lithospheric stresses for a dynamic Earth

Ann. Geophys., 2 (1984), pp. 267-286

Y. Ricard, M.A. Richards, C. Lithgow-Bertelloni, Y. LeStunff 
Geodynamic model of mantle density heterogeneity

J. Geophys. Res., 98 (1993), pp. 21895-21909

M. Richards, B.H. Hager

Geoid anomalies in a dynamic Earth

J. Geophys. Res., 89 (1984), pp. 5987-6002

J. Ritsema, H.J. van Heijst, A. Deuss, J.H. Woodhouse

S40RTS: a degree-40 shear-velocity model for the mantle from new Rayleigh wave dispersion, teleseismic traveltimes, and normal-mode splitting function measurements

Geophys. J. Int., 184 (2011)

H.J. Ritsema, J.H. van Heijst, J.H. Woodhouse

Complex shear velocity structure beneath Africa and Iceland

Science, 286 (1999), pp. 1925-1928

J. Roger, J.P. Platel, C. Cavelier, C.B.D. Grisac

Donnees nouvelles sur la stratigraphie et l'histoire geologique du Dhofar (Sultanat d'Oman)

Bull. Soc. Geol. France, 5 (1989), pp. 265-277

G. Salaün, H. Pedersen, A. Paul, V. Farra, H. Karabulut, D. Hatzfeld, C. Papazachos, D.M. Childs, C. Pequegnat, the SIMBAAD Team

High resolution surface wave tomography beneath the Aegean-Anatolia region: constraints on upper mantle structure

Geophys. J. Int., 190 (2012), pp. 406-420

A.M.C Şengör, S. Özeren, T. Genç, E. Zor

East Anatolian high plateau as a mantle-supported, north-south shortened domal structure

Geophys. Res. Lett., 30 (2003), p. 2003

A.M.C. Şengör

R. Ernst, K. Buchan (Eds.), Elevation as Indicator of Mantle Plume Activity, vol. 352Geological Society of America Special Paper (2001), pp. 183-225

A.M.C. Şengör, M.S. Özeren, M. Keskin, M. Sakınç, A.D. Özbakır, I. Kayan

Eastern Turkish high plateau as a small Turkic-type orogen: implications for postcollisional crust-forming processes in Turkic-type orogens

Earth Sci. Rev., 90 (1-2) (2008), pp. 1-48

http://dx.doi.org/10.1016/j.earscirev.2008.05.002

A.M.C. Şengör

The North Anatolian transform fault: its age, offset and tectonic significance

J. Geol. Soc. (London), 136 (1979), pp. 269-282 
A.M.C Şengör, O. Tüysüz, C. İmren, M. Sakınç, H. Eyidoğan, N. Görür, X. Le Pichon, C. Rangin

The North Anatolian fault: a new look

Annu. Rev. Earth Planet. Sci., 33 (2005), pp. 37-1112

http://dx.doi.org/10.1146/Annrev.earth.32.101802.120415

J.A. Shaw, J.A. Baker, M.A. Menzies, M.F. Thirlwall, K.M. Ibrahim

Petrogenesis of the largest intraplate volcanic field on the Arabian Plate (Jordan): a mixed lithosphere-asthenosphere source activated by lithosphere extension

J. Petrol., 44 (9) (2003), pp. 1657-1679

http://dx.doi.org/10.1093/petrology/egg052

Siebert, L., Simkin, T., 2002. Volcanoes of the World: An Illustrated Catalog of Holocene Volcanoes and Their Eruptions. Smithsonian Institution. GVP-3, Global Volcanism

Program Digital Information Series. Available from: 〈http:www.earthchem.org .

N.A. Simmons, A.M. Forte, L. Boschi, S.P. Grand

GyPSuM: a joint tomographic model of mantle density and seismic wave speeds

J. Geophys. Res., 115 (2010), p. B12310 http://dx.doi.org/10.1029/2010JB007631

N.A. Simmons, A.M. Forte, S.P. Grand

Thermochemical structure and dynamics of the African superplume

Geophys. Res. Lett., 34 (2) (2007), p. L02301

http://dx.doi.org/10.1029/2006GL028009

N. Simmons, A. Forte, S.P. Grand

Joint seismic, geodynamic and mineral physical constraints on three-dimensional mantle heterogeneity: implications for the relative importance of thermal versus compositional heterogeneity

Geophys. J. Int., 177 (2009), pp. 1284-1304 http://dx.doi.org/10.1111/j.1365-

246X.2009.04133.X

G. Stadler, M. Gurnis, C. Burstedde, L.C. Wilcox, L. Alisic, O. Ghattas

The dynamics of plate tectonics and mantle flow: from local to global scales

Science, 329 (2010), pp. 1033-1038

J. Steinberg, Z. Gvirtzman, Y. Folkman, Z. Garfunkel

Origin and nature of the rapid late Tertiary filling of the Levant Basin

Geology, 39 (4) (2011), pp. 355-358

R. van der Voo, W. Spakman, H. Bijwaard

Tethyan subducted slabs under India

Earth Planet. Sci. Lett., 171 (1999), pp. 7-20

D.G. van der Meer, W. Spakman, D.J.J. van Hinsbergen, M.L. Amaru, T.H. Torsvik

Towards absolute plate motions constrained by lower-mantle slab remnants

Nat. Geosci., 3 (2010), pp. 36-40

D.J.J. van Hinsbergen, B. Steinberger, P. Doubrovine, R. Gassmöller

Acceleration-deceleration cycles of India-Asia convergence: roles of mantle plumes and continental collision

J. Geophys. Res., 116 (2011), p. B06101 http://dx.doi.org/10.1029/2010JB008051 
D.J.J. van Hinsbergen, E. Hafkenscheid, W. Spakman, J.E. Meulenkamp, R. Wortel Nappe stacking resulting from subduction of oceanic and continental lithosphere below Greece

Geology, 33 (4) (2005), pp. 325-328 http://dx.doi.org/10.1130/G20878.1

D.J.J. van Hinsbergen, N. Kaymakcl, W. Spakman, T.H. Torsvik

Reconciling the geological history of western Turkey with plate circuits and mantle tomography

Earth Planet. Sci. Lett., 297 (2010), pp. 674-686

D.J.J. van Hinsbergen, S.M. Schmid

Map-view restoration of Aegean-west Anatolian accretion and extension since the Eocene

Tectonics, 31 (2012), p. TC5005 http://dx.doi.org/10.1029/2012TC003132

F. Watchorn, G.J. Nichols, D.W.J. Bosence

Rift related sedimentation and stratigraphy, southern Yemen (Gulf of Aden)

B.H. Purser, D.W.J. Bosence (Eds.), Sedimentation and Tectonics of Rift Basins:

Red Sea-Gulf of Aden, Chapman and Hall, London (1998), pp. 165-189

A. Wüstefeld, G.H.R. Bokelmann, G. Barruol, J.P. Montagner

Identifying global seismic anisotropy patterns by correlating shear-wave splitting and surface-wave data

Phys. Earth Planet. Inter., 176 (2009), pp. 198-212 Available from:

V.V. Yarmolyuk, O.A. Bogatikov, V.I. Kovalenko

Late Cenozoic transcontinental features and the magmatism in the Earth's EuroAfrican segment and the geodynamics of their evolution

DAN, 395 (1) (2004), pp. 91-95

S. Zhong, M.T. Zuber, L. Moresi, M. Gurnis

Role of temperature-dependent viscosity and surface plates in spherical shell models of mantle convection

J. Geophys. Res., 105 (2000), pp. 11063-11082

E. Zilberman

Landscape Evolution in the Central and Northern Negev in the Neogene and the Quaternary

Geological Survey of Israel, (1991) 164 pp 